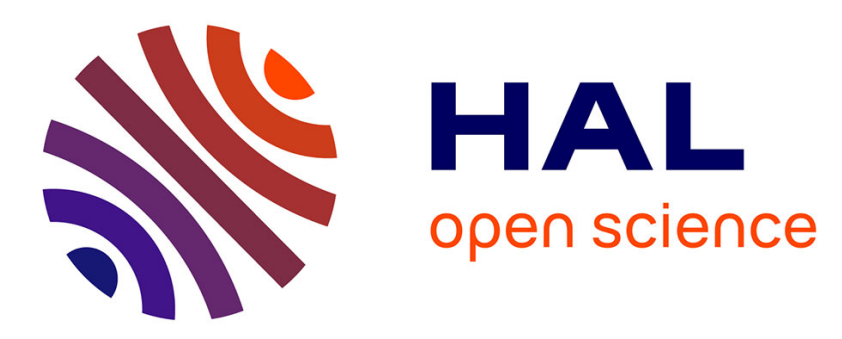

\title{
Large-scale strain localization induced by phase nucleation in mid-crustal granitoids of the south Armorican massif
}

Nicolas Mansard, Hugues Raimbourg, Romain Augier, Jacques Précigout, Nicole Le Breton

\section{To cite this version:}

Nicolas Mansard, Hugues Raimbourg, Romain Augier, Jacques Précigout, Nicole Le Breton. Largescale strain localization induced by phase nucleation in mid-crustal granitoids of the south Armorican massif. Tectonophysics, 2018, 745, pp.46-65. 10.1016/j.tecto.2018.07.022 . insu-01856944

\section{HAL Id: insu-01856944 https://hal-insu.archives-ouvertes.fr/insu-01856944}

Submitted on 13 Aug 2018

HAL is a multi-disciplinary open access archive for the deposit and dissemination of scientific research documents, whether they are published or not. The documents may come from teaching and research institutions in France or abroad, or from public or private research centers.
L'archive ouverte pluridisciplinaire HAL, est destinée au dépôt et à la diffusion de documents scientifiques de niveau recherche, publiés ou non, émanant des établissements d'enseignement et de recherche français ou étrangers, des laboratoires publics ou privés. 


\section{Accepted Manuscript}

TEGTONOPHYSICS

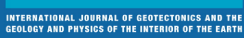

Large-scale strain localization induced by phase nucleation in mid-crustal granitoids of the south Armorican massif

Nicolas Mansard, Hugues Raimbourg, Romain Augier, Jacques Précigout, Nicole Le Breton

PII:

S0040-1951(18)30265-8

DOI: doi: $10.1016 /$ j.tecto.2018.07.022

Reference: TECTO 127898

To appear in:

Tectonophysics

Received date:

23 February 2018

Revised date:

6 June 2018

Accepted date:

25 July 2018

Please cite this article as: Nicolas Mansard, Hugues Raimbourg, Romain Augier, Jacques Précigout, Nicole Le Breton, Large-scale strain localization induced by phase nucleation in mid-crustal granitoids of the south Armorican massif. Tecto (2018), doi:10.1016/ j.tecto.2018.07.022

This is a PDF file of an unedited manuscript that has been accepted for publication. As a service to our customers we are providing this early version of the manuscript. The manuscript will undergo copyediting, typesetting, and review of the resulting proof before it is published in its final form. Please note that during the production process errors may be discovered which could affect the content, and all legal disclaimers that apply to the journal pertain. 


\section{Large-scale strain localization induced by phase nucleation in mid-crustal}

\section{granitoids of the south Armorican massif}

Nicolas Mansard', Hugues Raimbourg ${ }^{1}$, Romain Augier ${ }^{1}$, Jacques Précigout ${ }^{1}$, Nicole Le Breton $^{l}$

${ }^{1}$ Institut des Sciences de la Terre d'Orléans (ISTO), UMR 7327, CNRS/BRGM, Université d'Orléans, 45071 Orléans, France

Research article submitted for publication in Tectonophysics.

Corresponding author at: UMR 7327, Institut des Sciences de la Terre d'Orléans (ISTO), Université d’Orléans, 1A rue de la Férollerie, 45071 Orléans, France.

E-mail addresses : nicolas.mansard@cnrs-orleans.fr (N. Mansard), hugues.raimbourg@univ-orleans.fr (H. Raimbourg), romain.augier@univ-orleans.fr (R. Augier), jacques.precigout@univ-orleans.fr (J. Précigout), nicole.le-breton@univ-orleans.fr (N.Le Breton).

Abstract

The reduction of grain size is believed to play a critical role in strain localization to form shear zones. Although many mechanisms have been proposed, the source of grain size reduction remains debated. The South Armorican Shear Zone (SASZ) is a crustal-scale strike-slip fault that deforms granitoids at mid-crustal conditions. The SASZ records the transition from protolith to ultramylonite, representative of increasing ductile shear strain. To investigate the evolution of strain localization, the different states of deformation were studied using a combination of detailed microstructural, chemical and electron backscatter diffraction analyzes. Increasing strain from protolith to ultramylonite resulted in (1) grain size reduction, (2) the development of interconnected monophase layers of mica and incipient mixed-phase zones composed of phengite-quartz \pm K-feldspar in protomylonite and lowstrain mylonite, and (3) the formation of fine-grained mixed-phase zones composed of K-feldspar- 
quartz \pm phengite in high-strain mylonite and ultramylonite. We propose that the causes for interconnection of mica are the formation of cracks in the protolith combined with fluid-assisted nucleation. The latter process also plays a major role in phase mixing, as attested by the precipitation of K-feldspar at triple junctions in quartz-rich layers and in fine-grained tails of inherited K-feldspar porphyroclasts in ultramylonite. The transition from quartz-rich layers and mixed-phase zones is accompanied by a strong dispersion of the quartz lattice preferred orientation. These microstructural and textural evidences suggest that phase nucleation is the major process behind phase mixing, possibly accompanied by the action of grain-boundary sliding to open cavities during deformation. Instead of a single process, we therefore highlight a succession of weakening processes in the evolution of the SASZ, starting with the crystallization of mica as a first weakening material, and then evolving with the formation of very fine-grained mixed-phase zones made principally of feldspar, quartz and phengite.

\section{Keywords}

Strain localization; phase mixing; dislocation creep; diffusion creep; phase nucleation 


\section{Introduction}

Strain localization in ductile shear zones is commonly characterized by the development of protomylonite, mylonite and fine-grained ultramylonite with increasing strain (e.g. Kilian et al., 2011; Linckens et al., 2011). As accommodating a large part of strain in large-scale structures, they play a crucial role for the dynamics of mountain belts, subduction zones or rifting. However, their occurrences have been considered as resulting from one or several processes of rheological weakening, the origins of which remain today very elusive (e.g. Stünitz and Fitz Gerald, 1993; Fliervoet et al., 1997; Fossen and Cavalcante, 2017). Investigating the processes responsible for largescale strain localization is essential to understanding the behaviour of the lithosphere-scale structures over geological timescale.

Several processes have been proposed and first introduced in Poirier (1980) and White et al. (1980) to account for a local weakening during deformation. They include the occurrence of (1) metamorphic reactions (2) geometric softening (3) chemical softening (4) a change in deformation mechanism owing to grain size reduction (5) shear heating and/or (6) pore fluid pressure effects. In polyphase rocks, the presence of different phases with various strengths may also be an important cause of ductile strain localization, as they produce a framework of interconnected weak layers (e.g. Jordan, 1988; Handy, 1990; Shea and Kronenberg, 1993; Dell'Angelo and Tullis, 1996; Lonka et al., 1998; Stewart et al., 2000; Holyoke and Tullis, 2006). Of further interest is the mechanism related to grain size reduction as it systematically occurs in ductile shear zones (e.g. White et al., 1980; Rutter and Brodie, 1988; Herwegh et al., 2011; Kilian et al., 2011; Montési and Hirth, 2003; Platt, 2015). The role of grain size reduction in strain localization thus deserves a special attention. Moreover, grain size reduction may give rise to substantial weakening when the mean grain size is small enough for grain size-sensitive (GSS) creep to control the bulk rock rheology (e.g. Boullier and Gueguen, 1975; Etheridge and Wilkie, 1979; Rutter and Brodie, 1988; Stünitz and Fitz Gerald, 1993; Fliervoet et al., 1997; De Bresser et al., 1998; Kruse and Stünitz, 1999; Kenkmann and Dresen, 2002; Précigout et al., 
2007; Raimbourg et al., 2008; Linckens et al., 2011; Kilian et al. 2011; Viegas et al., 2016). Nevertheless, the sources of grain size reduction still remain poorly constrained and require further detailed studies of shear zones, particularly for polyphase rocks through large-scale structures.

In this contribution, we investigate the microstructural features of a granitoid mylonitized within a major crustal shear zone of South Brittany, Western France. This shear zone corresponds to the historical place of first recognition of S-C and S-C' fabrics (Berthé et al., 1979). Here, we focus on the strain gradient outlined by a gradual grain size reduction from undeformed protolith to ultramylonite. Using light microscope, cathodoluminescence (CL), backscattered electron (BSE) imaging along with electron backscatter diffraction (EBSD) analyzes, we describe the progressive evolution of the microstructure and associated changes in active deformation processes.

\section{Geological setting}

The French Armorican massif corresponds to one of the largest pieces of the Paleozoic Variscan orogenic belt, which extends throughout western and central Europe (e.g. Matte, 1991, 2001). The Variscan belt resulted from the collision between two major continental domains, the Gondwana continent to the south and the Laurussia continent to the north.

The structural pattern of the Armorican massif is dominated by late-Carboniferous W-E to NW-SE striking, dextral strike-slip shear zones, namely the North Armorican shear zone (NASZ) and South Armorican shear zone (SASZ) (e.g. Watts and Williams, 1979; Jégouzo, 1980; Matte, 1986; Tartèse et al., 2011). In the Armorican massif, the formation of crustal-scale shear zones is associated with widespread extension and magmatism during the collapse of the Variscan orogenic belt (e.g. Berthé et al., 1979; Jégouzo, 1980; Vigneresse and Brun, 1983; Ballèvre et al., 2009). Macrostructural studies demonstrated that deformation localized over time towards the contact between syntectonic plutons and host rocks (e.g. Berthé et al., 1979). From a paleogeographic point of view, the Armorican massif is divided into three main distinct parts, namely the Léon, North-Central and South-Armorican 
domains, all bound by major tectonic contacts including suture zones such as the Nort-sur-Erdre deformed zone (Fig. 1a, e.g. Cartier and Faure, 2004; Faure et al., 2005, Ballèvre et al., 2009). These domains drastically differ from each other by their metamorphic grade and structural style (e.g. Gumiaux et al., 2004; Faure et al., 2008; Ballèvre et al., 2009; Turrillot et al., 2011; Augier et al., 2015).

The SASZ extends over hundreds of kilometers and represents a major structural zone that separates the North-Central and South Armorican domains (Fig. 1a). The SASZ is divided into two main branches roughly oriented WNW-ESE for the northern branch and NW-SE for the southern branch (Fig. 1a; e.g. Cogne, 1960; Jégouzo, 1980). The southern branch separates the South Armorican domain in two parts: 1) the Ligerian Domain to the North characterized by Early Paleozoic ophiolites, high-pressure mafic and felsic rocks (Ballèvre et al., 1994; Bosse et al., 2000), and 2) the coastal South Armorican domain, which exhibits metamorphic and granitic rocks (Brown and Dallmeyer, 1996; Turrillot et al., 2009, 2011; Augier et al., 2015).

The present study focuses on the southernmost parts of the Ligerian Domain along the Southern branch of the SASZ, where Neoproterozoic to Lower Paleozoic metasediments are intruded by Carboniferous granitoids traditionally described as synkinematic intrusion (Fig. 1b; e.g. Berthé et al., 1979; Tartèse and Boulvais, 2012). These granitoids are affected by a variable strain intensities, giving rise to local mylonites and ultramylonites (e.g. Berthé et al., 1979). This is notably the case for the Questembert granite, where strain increases southward and reaches a maximum in the core of the Southern branch of the SASZ (Fig. 1b; e.g. Augier et al., 2011; Tartèse et al., 2012).

The studied samples were collected along a section through a satellite body of the Questembert granite massif (Fig. 1b-c). This section represents a strain gradient from undeformed or slightly deformed host rocks of the SASZ (domain 1) towards the most deformed, ultramylonitic sample in the core of the SASZ (domain 5). Accordingly, the grain size decreases and the foliation progressively transposes into the shear plane from domain 1 to domain 5 (Fig. 1c). This section has been also completed by another sample collected in the Lescastel quarry to allow comparison with very recent results of Bukovská et al. (2016) (Fig.1b). 


\section{Material and Methods}

Thin sections were cut parallel to the stretching lineation and perpendicular to the foliation (XZ plane). Microstructural and chemical evolution of the different finite strain states were studied using optical microscopy, cathodoluminescence (CL) imaging, electron backscatter diffraction (EBSD), and electron probe micro-analysis (EPMA).

\subsection{Analytical Methods}

To perform a CL analysis, the sections were placed in a vacuum chamber at Argon pressure of $\sim 60 \times 10^{-3}$ mbar. They were irradiated by a cold cathode source electron gun provided by OPEA (France). Standard tension-current beam conditions were maintained at $\sim 13-15 \mathrm{kV}$ and $90-110 \mu \mathrm{A}$, respectively. The angle between the gun axis and thin section plane was set to $18^{\circ}$. The chamber was placed on a simplified optical mount designed to minimize light absorption on the beam pathway. The optical stage was equipped with a Retiga 2000R 1394a cooled camera (captor size 1 inch, resolution 1600 x1200 pixel $^{2}$, square pixel size $\left.7.4 \mu \mathrm{m}\right)$. Acquisition time was fixed to ca. $10 \mathrm{~s}$ for quartz and micas and ca. $2 \mathrm{~s}$ for feldspars.

EBSD was carried out with an EDAX PEGASUS EDS/EBSD system and OIM DC 6.4 software (manufacturer EDAX, Mahwah - USA) at the BRGM (Orléans, France). The polishing procedure of thin sections includes chemico-mechanical polishing using first diamond paste of 0.25 $\mu \mathrm{m}$ followed by colloidal silica. The operating conditions involved an accelerating voltage of $20 \mathrm{kV}$, a working distance of 15 or $18 \mathrm{~mm}$, and a probe current of $\sim 6 \mathrm{nA}$. The EBSD data were processed to produce orientation maps and equal-area lower-hemisphere pole figures plotted as 'one-point-pergrain' in order to give the same weight to all grains independently of their size. The grains are defined so that their boundaries involve a minimum misorientation angle of $10^{\circ}$. The iso-contours on pole 
figures were plotted using the $\mathrm{OIM}^{\mathrm{TM}}$ - EDAX software. Latice preferred orientation (LPO) strength was quantified using the texture (J) and misorientation (M) indices (Bunge, 1982; Skemer et al., 2005). Pole figures and J-index were collected considering a Gaussian half-width angle of $10^{\circ}$.

Mineral compositions were collected using a CAMECA SX Five EPMA at the ISTO-BRGM (Orléans, France) on carbon-coated thin sections (20 nm thickness). The analyzes were carried out with an accelerating voltage of $15 \mathrm{kV}$, a beam current of $\sim 6 \mathrm{nA}$ and a beam size of ca. $1 \mu \mathrm{m}$.

\subsection{Quantitative Microstructural Study}

Scanning electron microscope/backscattered electron (SEM/BSE) and light microscope images have been used to determine grain size distributions of quartz. Within each strain domain, grains in quartz-rich areas have been digitized manually. To ensure statistical representation of data, about 22000 quartz grains were processed. The grains were then analyzed using the software ImageSXM® (http://www.ImageSXM.org.uk) to quantify the grain size, grain contact frequency (GCF) and shape preferred orientation (SPO).

Two types of source images were used to quantify the grain size: transmitted light microscope images when grains were easily distinguishable and SEM/BSE images when the grain size was too small, including zones of mixed phases in mylonites and ultramylonites. The number weighted grain size was defined as the diameter of equivalent circular diameter $\left(\mathrm{d}_{\mathrm{equ}}=2 \mathrm{x} \sqrt{\left(\frac{\text { area }}{\pi}\right)}\right)$. The grain contact frequency (GCF) between quartz-quartz (Q-Q), feldspar-feldspar (F-F) and quartz-feldspar (Q-F) was evaluated using the method described by Heilbronner and Barrett (2014). In this method, GCF between grains is expressed as deviation from a random phase distribution. Results of GCF allowed us to define spatial distributions of grains as clustered or ordered, corresponding to an increasing degree of phase mixing. For a two-phase mixing where grains are randomly distributed, Heilbronner and Barrett (2014) define pQQ, pFF, and pQF as the predicted amount of quartz/quartz, feldspar/feldspar and quartz/feldspar boundaries, respectively. For a two-phase mixing $\mathrm{pQ}$ and $\mathrm{pF}$ are defined as phase 
proportion where $\mathrm{pQ}+\mathrm{pF}=1$. The random phase distribution that separates clustered and ordered domains is described by the following equations as a function of phase proportions:

$$
\begin{aligned}
& \mathrm{pQQ}=\mathrm{pQ} \cdot \mathrm{pQ}=\mathrm{pQ}^{2} \\
& \mathrm{pFF}=\mathrm{pF} \cdot \mathrm{pF}=(1-\mathrm{pQ})^{2} \\
& \mathrm{pQF}=\mathrm{pQ} \cdot \mathrm{pF}+\mathrm{pF} \cdot \mathrm{pQ}=2 \mathrm{pQ}(1-\mathrm{pQ})
\end{aligned}
$$

The fraction of Q-F contacts is higher than a random distribution for the "ordered" case, and the relationship is opposite for the "clustered" case. Accordingly, the fractions of Q-Q and F-F contacts are lower and higher than a random distribution for ordered and clustered cases, respectively (Heilbronner and Barrett, 2014). In other words, ordered/clustered distribution implies a higher/smaller mixing degree of phases and a larger/smaller fraction of interphase boundaries than random distribution. In addition, the SPO analysis was performed using the PAROR method (Panozzo, 1983), and the preferred orientation of each grain shape distribution was plotted in a rose diagram. The aspect ratio $\mathrm{b} / \mathrm{a}$ (where $\mathrm{a}$ and $\mathrm{b}$ are the long and short axis of best-fit ellipses approximating the grain shape) was also determined to document the bulk grain shape anisotropy.

\subsection{Bulk-rock compositions}

Bulk-rock chemical analyzes of the samples investigated and used in pseudosection calculations are given in Table 1. Analyzes were carried out in the Centre de Recherches Pétrographiques et Géochimiques (CRPG-Nancy) by the Service d'Analyse des Roches et des Minéraux (SARM). Phase relationships were determined using the Perple_X thermodynamic software (Connolly, 2005), version 6.7.9 with the thermodynamic database of Holland and Powell (2004). These relationships were modeled in the NCKFMASH system (Na2O-CaO-K2O-FeO-MgO-Al2O3$\mathrm{SiO} 2-\mathrm{H} 2 \mathrm{O}$ ) with water in excess and pure albite phase excluded (only solid solution of plagioclase). 


\section{Results}

\subsection{Microstructural evolution - qualitative approach}

\subsubsection{Strain facies across the strain gradient}

The Questembert granite is traditionally described as a large-scale synkenimatic intrusion (e.g. Berthé et al., 1979; Tartèse and Boulvais, 2010). However, microscopic-scale observations showed no evidence for the presence of melts during deformation even in low-strain domains (Bouchez et al., 1992). It is mainly composed of quartz (qtz), K-feldspar (kf), plagioclase (pl) and white mica (wm) with minor amounts of biotite (bt), apatite (ap), chlorite and kaolinite. Solid-state deformation is characterized by a strain gradient from a quasi-undeformed protolith to a $\mathrm{km}$-scale ultramylonite where grain size is strongly reduced (Fig. 1c). This aspect is considered in terms of strain gradients based on microstructural observations, including grain size and evolution of porphyroclast/matrix proportions as major parameters. We thus use changes in grain size and proportion of porphyroclast/matrix with respect to the protolith as proxy to define several domains of strain intensity, such as described in the following sections. In order to avoid ambiguity when considering quartz aggregates and their possible polymineralic character, the term "quartz-rich aggregates/layers" will be used in this text when referring to the domains of quartz with a volumetrically minor amount of second phases. In addition, the term "nucleation" will also be used to denote the processes involving changes in chemical composition, unlike dynamic recrystallization.

\subsubsection{Low-strain protolith}

The protolith contains abundant porphyroclasts of K-feldspar, plagioclase, mica and quartz, without discernible shape-preferred orientation. Quartz grain boundaries have variable geometries, 
from slightly curved to serrated (Fig. 2a). These quartz grains show weak deformation features such as sweeping or patchy undulatory extinction (Fig. 2b). In this low-strain protolith, both biotite and white micas are present in a comparable amount. These micas are either undeformed or slightly kinked and bent. Quartz-rich aggregates are associated with cracks along grain boundaries filled with biotite and white mica that form essentially at the edges of porphyroclasts (Fig. 2c). Small grains of white mica are also distributed in plagioclase as rod-like cross-sections (Fig. 2d). Plagioclase grains form large porphyroclasts locally twinned, rarely bent, and affected by fractures (Fig. 2b). K-feldspar porphyroclasts are also frequently fractured. Some of the fractures that crosscut feldspar porphyroclasts are filled by quartz, plagioclase, white mica and biotite (Fig. 2b). K-feldspar porphyroclasts are strongly perthitic, with plagioclase exsolution lamellae (Fig. 2e). Commonly, plagioclase nucleates in many different places within and at the rim of K-feldspar grains (Fig. 2d-e). Both types of feldspar are almost undeformed, such as shown by smooth undulatory extinction and limited chemically-driven nucleation at grain boundaries.

\subsubsection{Medium-strain protomylonite}

The protomylonite samples are microstructurally and geographically close (Fig. 1b) to the one collected by Bukovská et al. (2016). Three main different types of mica microstructures are identified in the protomylonite: (1) small aligned white mica grains form disconnected trails along the grain boundaries in quartz-rich layers (Fig. 3a-b), (2) some thin and short monophase layers of mica form an anastomosing network connected by trails of very fine-grained recrystallized grains inherited from mica porphyroclasts (Fig. 3c-d), and (3) a few fine-grained polyphase layers mainly composed of mica and quartz (Fig. 3e). These mica-quartz-rich polyphase layers are subparallel to the foliation, cross-cut quartz-rich layers and wrap around feldspar porphyroclasts (Fig. 3e). The polyphase layers increase the proportion of matrix compared with the protolith. With respect to the overall size of recrystallized quartz grains, the quartz grain size is considerably smaller in these high-strain narrow zones, where elongated white micas are present in large amounts (Fig. 3e). Very few chlorite grains in the layers are also observed. 


\subsubsection{High-strain mylonite}

The mylonite is composed of a network of polyphase layers wrapping up isolated relic domains in which inherited large porphyroclasts are still visible (i.e., microlithons; Fig. 4a). Some feldspar porphyroclasts are fragments resulting from fracturing of initially larger grains. While the feldspar porphyroclasts are smaller in size and in volume fraction than those in the protomylonite, biotite and monophase layers of mica are no longer present. With respect to the protomylonite, the amount of mica-quartz-rich polyphase layers increases (Fig. 4a-b-c). Within these polyphase layers, white mica grains are strongly aligned and become interconnected (Fig. 4b-c). A large amount of apatite is also documented in these deformed zones (Fig. 4b). The pervasively recrystallized quartz grains exhibit a shape-preferred orientation nearly parallel to the mylonitic foliation (Fig. 4c). The clasts of plagioclase and K-feldspar locally occur in these zones in small quantities (Fig. 4b-c).

The mylonite is also distinguished from the protomylonite by the incipient development of other fine-grained polyphase layers enriched in quartz and K-feldspar (Fig. 4d-e). While micas are scarce in these layers, isolated grains of K-feldspar exist at triple junctions of quartz grains (Fig. 4f). Within these polyphase layers, plagioclase grains occur as clasts. Fracturing is dominant in plagioclase although a marginal nucleation of plagioclase promotes the formation of fine grains at the boundaries of the old grains. In some places, the remaining K-feldspar porphyroclasts are completely rimmed and replaced by plagioclase (Fig. $4 \mathrm{~g}$ ).

These types of fine-grained polyphase layers isolate domains where the grain size is much larger and where less deformed porphyroclasts can still be recognized. Outside of the fine-grained polyphase layers, the quartz-rich layers are highly elongated subparallel to the foliation and their grains reveal patchy or sweeping undulose extinction patterns and the presence of subgrains (Fig. 4h). Locally, new small grains of quartz recrystallize within older, larger grains of quartz (Fig. 4i). 


\subsubsection{Very high-strain ultramylonite}

The ultramylonite is largely composed of a succession of foliation-forming parallel layers of fine grains that embed few small clasts, forming a clast-in-matrix microstructure. These latter are plagioclase grains (Fig. 5a-b), and more rarely K-feldspar and white mica grains (Fig. 5a-c). Tails around K-feldspar clasts are composed of fine-grained quartz and K-feldspar (Fig. 5c). The finegrained parallel layers are either composed of quartz-rich layers, or of polyphase layers of quartz, Kfeldspar and white mica (Fig. 5d). The vast majority of the ultramylonite consist of these polyphase layers, while quartz-rich layers occur sparsely in the form of elongated domains parallel to the foliation.

\subsubsection{Microstructural evolution across the strain gradient}

The prominent microstructural features of the investigated strain gradient are the grain size reduction, the formation of monophase layers of mica and polyphase layers. With increasing strain, coarse-grained mineral phases like feldspar, quartz and mica are replaced by fine-grained layers (Fig. 4-5-6). The grain size reduction of coarse-grained feldspar occurs predominantly by fracturing and nucleation of new grains with a different mineralogical composition than the protolith (Fig. 6). New grains are mostly distributed along the margins of old magmatic feldspar porphyroclasts, or within the tails of porphyroclasts (Fig. 6). The pink K-feldspar that composes the fine-grained mixed zones in the most strongly deformed domains is the same as the one that composes the rims of the coarse-grained light blue K-feldspar present in the protolith and the protomylonite (Fig. 6). Similarly, the plagioclase grains present in the ultramylonite are also observed as reaction products of the coarse-grained plagioclase of the protolith. These CL properties of K-feldspar and plagioclase support the connection of the microstructures throughout the strain gradient: high-strain domains (ultramylonite and mylonite) 
are therefore interpreted as the evolution, with increasing strain, of low strain domains (protolith and protomylonites).

\subsubsection{Layers of mixed phases}

The transition from protolith to ultramylonite is characterized by the development of finegrained polyphase layers, i.e. fine-grained mixed-phase zones (Fig. 7), which include three different types depending on their phase content (Fig. 7a-c-e). The mixed-phase zones also contain plagioclase, but only locally and in very small amounts (hence not shown in images of Fig. 7). The first type (type I) involves the presence of white mica and quartz in equal proportion with minor K-feldspar (Fig. 7ab). While scarce in the protomylonite, this mixed-phase assemblage is abundant in the anastomosing network of the mylonite polyphase layers. The two other mixed-phase zones (types II and III) are composed of quartz + feldspar and contain smaller amounts of white mica. They are very similar and simply differ by the nature of the major phase, either represented by K-feldspar (Fig. 7c-d) or quartz (Fig. 7e-f). Types II and III mixed-phase zones are observed in high-strained zones of the mylonites (domain 4), and most of the polyphase layers in ultramylonite. The micas form a partially interconnected network in type I mixtures (Fig. 7b), but they form isolated grains in types II and III (Fig. 7c-f). All fine-grained mixed-phase zones may also contain few very small clasts of mica, plagioclase, or K-feldspar.

In all of these zones, the grains of white mica show a SPO with a mean long axis subparallel to the foliation and an aspect ratio of $\sim 0.32$ (Fig. 7b-d-f). The quartz grains are preferentially elongated parallel to the foliation in type I mixture (aspect ratio of $\sim 0.46$; Fig. $7 \mathrm{~b}$ ), but they have a much more equant shape in type II and III mixtures (aspect ratio of $\sim 0.72$; Fig. 7d-f). The small grains of Kfeldspar only present in type II and III mixtures also have more equant shape with aspect ratios of 0.72 and $\sim 0.60$, respectively (Fig. $7 d-6 f)$.

\subsection{Microstructural evolution - quantitative approach}


The micro-textural study detailed below is based on digitized maps of each strain domain (Fig. 8), particularly in quartz-rich areas. Figure 8 shows the main microstructural evolution with increasing strain, including the development of quartz-rich layers and monophase layers of mica in low-strain domains (Fig. 8b) and mixed-phase zones in higher strain domains (Fig. 8c-d-e).

\subsubsection{Grain size}

Overall, there is a significant decrease in quartz grain size (equivalent diameter) with increasing strain (Fig. 9a). While the median of quartz grain size is $170 \mu \mathrm{m}$ in domain 1 (protolith) and $120 \mu \mathrm{m}$ in domain 2 (protomylonite), it decreases in domains 3 and 4 (mylonites) with respective median sizes of $114 \mu \mathrm{m}$ and 38-29 $\mu \mathrm{m}$. A gradual narrowing of the grain size distribution is observed with a wide range of size in the weakly deformed domains (1 and 2) and a rather narrow distribution for the mylonitic domains ( 3 and 4 ). In mylonites, these grain sizes correspond to the quartz-rich layers in low-strain domains where no phase mixing occurs. In contrast, where mixed-phase zones are abundant in high-strain domains, the median equivalent diameter of quartz grains is strongly reduced to 5.4 in the mylonite and $2.3 \mu \mathrm{m}$ in ultramylonite (Fig. 9b). In these latter, a bimodal distribution of quartz grain size is observed (Fig. 9b). This is caused by the variable grain size distribution between polyphase mixed zones and preserved monophase aggregates in these high-strain domains. It is also worth to note that the recrystallized grain size of quartz in mixed-phase zones is similar and stable in mylonite and ultramylonite. The proportion of mixed-phase zones is more important in ultramylonite than in mylonite.

\subsubsection{Grain Contact Frequencies (GCF)}

The GCF between Q-Q, F-F and Q-F are shown in figure 9 as a function of the amount of boundary surface by these phases (Heilbronner and Barrett, 2014). Quartz grains are distributed in a clustered fashion for all domains (Fig. 10a). The GCF of quartz grains in the strongly deformed samples (strain domains 3 to 5) are closer to a random distribution than the ones in the weakly deformed samples (strain domains 1-2). With increasing strain, this implies an increase of the degree 
of mixing of quartz grains with other phases. Accordingly, the feldspar grains are organized in the ordered field for all domains (Fig. 10b), but once again, there is an evolution with strain. In the weakly deformed sample (strain domain 1), the GCF between feldspar grains are closer to the random distribution curve. Thus, with increasing strain (strain domains 2 to 5), the GCF between feldspar grains move away from the random distribution curve, suggesting an increase in the mixing degree of feldspar grains with the other phases. Regarding the GCF between quartz and feldspar grains, the weakly deformed samples (strain domains 1-2) are localized in the clustered domain, while the more strongly deformed samples (strain domains 3 to 5) are located in the ordered domain, notifying again an increase in the mixing degree of quartz and feldspar grains with increasing strain.

\subsubsection{Quartz Lattice Preferred Orientation (LPO)}

Using equal-area lower-hemisphere pole figures, we show in Fig. 11 the quartz LPO of mylonitic (Fig. 11a-b) and ultramylonitic layers (Fig. 11c-d). In the mylonite, the quartz-rich layer exhibits a moderate LPO (Fig. 11a). The pole figure of quartz c-axes [0001] shows an incomplete crossed girdle (Fig. 11a). In the ultramylonite, a moderate quartz c-axes [0001] single girdle is developed at a large angle to the foliation and follows the sense of shear (Fig. 11c). The a-axes [11-20] of these quartz-rich layers are scattered and show locally a minor maximum close to the lineation. All of these distributions are strongly dispersed first in fine-grained quartz located at the rim of the layers (Fig. 11a-c), and in fine-grained polyphase mixed zones of both the mylonite and ultramylonite (Fig. 11b-d). The decrease of fabric strength is outlined by the evolution of the J-index and M-index from quartz-rich layers $(\mathrm{J}=3.59$ and $2.51 ; \mathrm{M}=0.13$ and 0.11$)$ to polyphase mixed zones $(\mathrm{J}=1.63$ and 1.56; $\mathrm{M}=0.05$ and 0.02 ) of the mylonite and ultramylonite, respectively (Fig. 11).

\section{Mineral chemistry}


The bulk-rock and mineral chemical compositions are summarized in Table 1 and 2. and in the isocon diagram of Fig. 12 (Grant, 1986). The average concentration of an element in the protomylonite, mylonite and ultramylonite $\left(\mathrm{C}^{\mathrm{a}}\right)$ has been compared to the average concentration of this element in the protolith $\left(\mathrm{C}^{0}\right)$. All major element concentrations plot close to the line of constant concentration $\left(C^{a}=C^{0}\right)$, or close to the lines of $10 \%$ gain $\left(C^{a}=1.1 C^{0}\right)$ and $10 \%$ loss $\left(C^{a}=0.9 C^{0}\right)$. Thus, the comparison between the strain domains studied indicates the lack of major chemical variations during progressive mylonitization. Nevertheless, a slight enrichment in $\mathrm{K}_{2} \mathrm{O}-\mathrm{P}_{2} \mathrm{O}_{5}-\mathrm{MgO}$ and depletion in $\mathrm{Na}_{2} \mathrm{O}$ in the mylonite/ultramylonite compared to the protolith is reported (Fig. 12).

The chemical composition of white mica shows that the recrystallized grains are richer in celadonite component than the large magmatic white micas (Fig. 13a). Thus, the large magmatic white mica grains correspond to muscovite, whereas the fine recrystallized grains of white mica (especially abundant in mixed-phase zones) are phengites. The feldspar grains have a narrower compositional range (Fig. 13b-c), but within this narrow range we can observe a tendency of the recrystallized grains to be slightly richer in An-component for plagioclase (Fig. 13b). The K-feldspar in mixed-phase zones is richer in Or-component (Fig. 13c). The plagioclase grains also appear to have zoning patterns with a blue core and a brown rim in terms of cathodoluminescence colors (Fig. 5c), but no chemical variation is identified with the EPMA (Table 2).

To better characterize the P-T conditions based on mineral compositions, we further show two pseudosections in Fig. 14. Over a large range of pressures, temperatures and parageneses, K-feldspar, quartz, white mica, and plagioclase are all stable, i.e., the assemblage observed in high-strain domains. Nevertheless, in all of the predicted parageneses, additional accessory minerals are present in particular to incorporate $\mathrm{Fe}$ and $\mathrm{Mg}$. Above $320-350^{\circ} \mathrm{C}$, biotite is stable, whereas below this temperature range, chlorite is the stable phase. The predicted amount of these accessory minerals is very low (below $1 \%$ for chlorite and $2 \%$ for biotite; Fig. 14a), reflecting the very low concentration in Fe and $\mathrm{Mg}$ in the bulk-rock. The parageneses observed do not include any of the accessory minerals predicted by the pseudosection (clinozoisite, chlorite and biotite). On the other hand, we observed the destabilization of biotite in the evolution from the protolith to mylonite/ultramylonite, suggesting that 
deformation occurred at temperature lower than the biotite-out reaction. The plagioclase in finegrained polyphase layers shows compositional range between 3 and $8 \%$ of anorthite component. The molar isopleths in white mica (phengite) show that Si content of phengite is dependent on both, pressure and temperature and evolves from 3.06 per formula unit (p.f.u) in the high temperature/lowpressure side to 3.26 (p.f.u) in the low temperature/high-pressure side (Fig 13b). In addition, the $\mathrm{X}_{\mathrm{Mg}}$ ratio ranges between 0.36 and 0.43 (Fig. 14b). Phengite compositions do not show considerable variation in $\mathrm{Si}$ content between the strain domains. Nevertheless, there is an important range of composition (Si p.f.u) from 3.16 to 3.23 and $\mathrm{X}_{\mathrm{Mg}}$ molar ratio from 0.37 to 0.41 (Fig. 14b).

\section{Discussion}

\subsection{P-T conditions of deformation}

Across the South Armorican Shear Zone, previous petrological studies have shown that deformation occurred under greenschist to lower amphibolite facies metamorphic conditions, and strain localization took place below the low temperature biotite isograd $\left(300-350^{\circ} \mathrm{C}\right.$; e.g. Gapais and White, 1982; Bukovská et al., 2016). Our analyzes show a constant composition of the phengite in mixed zones across the strain gradient (Fig. 13a), which suggest constant P-T conditions during deformation, as the rock composition is also relatively constant.

Given the rock chemical composition, the P-T conditions of deformation are also constrained by the Fe/Mg-bearing phases (Fig. 14). Nevertheless, their predicted abundance is very small (clinozoisite/chlorite: below 1\%, biotite: below 2\%) (Fig. 14a). Based on their observation of chlorite in layers, Bukovská et al. (2016) defined the stability field for deformation as associated with the parageneses of chlorite, plagioclase, white mica, clinozoisite, microcline and quartz. The absence of clinozoisite in their microstructural study is explained by the substitution of the latter by another Cabearing phase such as apatite (Bukovská et al., 2016). Considering our microstructural observations, this is consistent with the large amount of apatite documented in the deformed zones (e.g. Fig. 4b). In the actual parageneses of our deformed samples, biotite is absent, while large biotite grains were 
present in the magmatic assemblage. On the other hand, chlorite is also in most cases absent in our high-strain samples and all $\mathrm{Fe}$ and $\mathrm{Mg}$ are completely taken up by the phengite, as can be approximately inferred from its modal abundance and composition (Table 1-2). When chlorite is present, its textural relationship with the mylonitic assemblage is rather unclear, casting some doubt on the stability of chlorite during deformation. There is therefore much uncertainty on the P-T conditions of deformation, even if the destabilization of biotite from the magmatic paragenesis and the intersection of compositional isopleths suggest that deformation occurred at temperatures below the biotite-out reaction curve, i.e., below $\sim 320-350^{\circ} \mathrm{C}$, similar to the conclusions of Gapais and White (1982) and Bukovská et al. (2016) (Fig. 14).

\subsection{Mechanisms of grain size reduction from protolith to ultramylonite}

Dynamic recrystallization is a major process for grain size reduction during plastic flow (e.g. Etheridge and Wilkie, 1979; Behrmann, 1985; Fliervoet and White, 1995; Kruse and Stünitz, 1999; De Bresser et al., 2001; Kenkmann and Dresen, 2002; Stipp et al., 2002), provided that the conditions of deformation in terms of grain size, temperature, pressure and differential stress are so that the rock deform in the dislocation creep regime (Hirth and Tullis, 1992; Passchier and Trouw, 2005). The pervasive occurrence of dynamic recrystallization is demonstrated in quartz microstructures (e.g. Fig. 4h), and results in strong grain size reduction (Fig. 9). The recrystallization microstructures are characterized by plastically elongated quartz-rich layers subparallel to the foliation (Fig. 4h). Their grains reveal patchy or sweeping undulose extinction patterns and the presence of numerous subgrains. More rarely, small bulges and new grains of quartz are developed along grain boundaries of old quartz grains (Fig. 4i). These observations involve subgrains rotation recrystallization (SGR) as the dominant dynamic recrystallization process of quartz, with a minor and local contribution to bulging recrystallization (BLG; e.g. Drury and Urai, 1990).

Grain size reduction can also result from (1) the nucleation of new grains of different composition (e.g. Kruse and Stünitz, 1999; Kenkmann and Dresen, 2002; Kilian et al., 2011; Herwegh 
et al., 2011; Platt, 2015; Précigout and Stünitz, 2016), (2) melt-rock reactions (Dijkstra et al., 2002), and/or (3) cataclasis/fracturing (e.g. Hippler and Knipe, 1990; Stünitz et al., 2003; Kruhl et al., 2007; Viegas et al., 2016). Owing to the lack of melt-rock reactions in shear zones formed under greenschist facies conditions, melting cannot be considered for grain size reduction. In these conditions, feldspar is generally expected to be mechanically strong, and grain size reduction is usually associated with nucleation, fracturing and reaction (e.g. Simpson and Wintsch, 1989; Hippertt, 1998; Tsurumi et al., 2003; Ree et al., 2005; Menegon et al., 2006).

The effect of nucleation of new grains to reduce the grain size is twofold. First, in itself, the nucleation of small grains is achieved at the expense of larger grains, which are affected by dissolution (Kilian et al., 2011), e.g. K-feldspar formed at triple junction in quartz aggregates (Fig. 4f). Second, nucleation of phase A within a cluster of grains of phase B result in pinning phase B grain boundaries (Fig. 3a-b; e.g. Kruse and Stünitz, 1999; Herwegh and Jenni, 2001; Herwegh and Berger, 2004; Song and Ree, 2007; Brodhag and Herwegh, 2010; Linckens et al., 2015; Hunter et al., 2016; Cross and Skemer, 2017; Gilgannon et al., 2017). In the early stages of deformation, quartz-rich layers reveal the presence of tiny white mica grains located along quartz grain boundaries (Fig. 3a-b). The small micas formed at grain boundaries inhibit the motion of quartz grain boundaries (Fig. 3a-b; e.g. Herwegh and Jenni, 2001; Linckens et al., 2015; Gilgannon et al., 2017). Such pinning acts against grain growth and maintains a small grain size (e.g. de Ronde et al., 2005; Linckens et al., 2015). This combined effect of nucleation to decrease the grain size is apparent in mylonites and ultramylonites, where the grain size of quartz is significantly larger in domains essentially composed of quartz compared to domains composed of quartz and feldspar (Fig. 9).

Feldspar grain size reduction is mainly induced by a combination of fracturing and nucleation, such as replacement reaction of $\mathrm{K}$-feldspar by plagioclase (Fig. 4g). This combination leads to the breakdown of the large porphyroclasts into smaller fragments (Fig. 6). Fracturing of feldspar and nucleation microstructures were described in natural shear zones deformed under greenschist facies conditions (e.g. Fitz Gerald and Stünitz, 1993; Ree et al., 2005) similar to the ones in this study (Fig. $2 b)$. In addition to its role of reducing the grain size, fracturing also enables fluid access and transport 
of elements required for nucleation to reduce the grain size (Fitz Gerald and Stünitz, 1993). Consequently, the dominant grain size controlling processes are dynamic recrystallization (quartz), nucleation of new grains with a different composition (feldspar and mica) and fracturing (feldspar).

\subsection{Formation of a weak mica network}

Mica is typically viewed as the weakest phase in granitoid rocks (e.g. Tullis and Wenk, 1994). The micas in the protolith are present as undeformed or only slightly bent magmatic phases. Locally, cracks filled with mica crosscut quartz-rich layers and typically occur at the tip of large magmatic micas (Fig. 2c). With increasing strain, the protomylonite exhibits newly formed micas that tend to organize into proto-layers, defined as an alignment of several micas parallel to each other and cutting across quartz-rich layers or precipitate along quartz grain boundaries (Fig. 3a-b). When located at quartz grain boundaries, these micas locally induce pinning of grain boundaries (e.g. Fig. 3a). With further evolution, an anastomosing network of monophase layers composed of mica starts to form (Fig. 3c). The onset of interconnection occurred where trails of very fine-grained phengites connect the large inherited grains of micas (Fig. 3c-d).

The formation of an interconnected weak layer microstructure requires the coalescence of the weak phases. The experiments of Dell'Angelo and Tullis (1996) investigated weak phase interconnection of quartz, while that of Holyoke and Tullis (2006) was more focused on mica interconnection. The latter proposes that stress concentration and brittle deformation in strong phases such as feldspar may induce weaker grains to become interconnected. Although the brittle deformation is mostly localized in feldspar porphyroclasts with a large number of fractures (Fig. 2b), cracks filled with mica are also observed in quartz-rich layers (e.g. Fig. 2c). These cracks occurred essentially at the tips of large mica grains where a phase strength contrast between quartz and mica is present. 
According to Holyoke and Tullis (2006), the stress concentration adjacent to weak phases may induce local brittle deformation, and could explain the formation of mica cracks crosscutting the quartz-rich layers. These cracks which are best preserved in low-strain domains, with limited ductile overprint, may enhance fluid access and then nucleation of grains that act as shear band precursors (e.g. Bukovská et al., 2016; Wehrens et al., 2016). Brittle deformation as evidenced by fractures is thus considered here as an initial important mechanism for localization of deformation, although its importance later decreases with a switch in dominant plasticity (e.g. Fusseis and Handy, 2008). The nucleation of micas in cracks and along quartz grain boundaries combined with the initial plasticity of old grains could lead to the interconnection of these weak phases. The low-temperature conditions of the SASZ deformation are in agreement with such an interplay between brittle and plastic deformation active at greenschist conditions (e.g. Passchier, 1984; Fusseis and Handy, 2008; Wehrens et al., 2016).

\subsection{Phase mixing with increasing strain}

\subsubsection{Evidence for nucleation of new grains}

The transition from weakly deformed samples to highly deformed ones is accompanied by grain size reduction and a gradual dispersion of quartz grains from aggregates to mixed-phase zones (Fig. 9). In the protolith, the protomylonite, and in some low-strain domains in mylonite, the quartz is arranged in quartz-rich layers (Fig. 3c-4h), while in high-strain domains in mylonite and ultramylonite the quartz is intimately mixed with other phases (Fig. 7c-e). Indeed, there is an increase in mixing concomitant with an increase of strain (Fig. 10). There is no or limited evolution between the mylonite and ultramylonite, neither between the protolith and protomylonite. The sharp increase towards mixing corresponds micro-structurally to the increase in polyphase mixed zones within mylonites (e.g. Fig. 4a-c-d). It is more than likely that between quartz-rich layers with small amounts of white mica and the first documented polyphase layers, i.e. fine-grained mixed zone rich in white mica and quartz, there must be transitions (Fig. 3b-e). The appearance of monophase layers of white mica may point towards such transitional microstructures (Fig. 3c). 
Dynamic recrystallization during plastic deformation, as a result of either SGR or grain boundary bulging, may reduce the grain size, but it is not expected to induce alone phase separation (Kilian et al., 2011). An additional process is required such as e.g. nucleation of new grains in dilatant sites to induce a spatial rearrangement of mineral phases, giving rise to phase mixing. Evidence of nucleation are first observed in the weakly deformed domains where fine-grained white micas occur along quartz grain boundaries (Fig. 3a-b), and in the form of small oriented particles in feldspar (Fig. 2d). Micas also filled fractures in feldspar clasts and quartz aggregates (Fig. 2b). Evidence of phase nucleation also includes the occurrence of isolated K-feldspar grains located at triple junctions in quartz-rich layers and in newly formed fine-grained mixed-phase zones (Fig. 4e-f-g; e.g. Kilian et al. 2011), and the local formation of tails of fine-grained quartz and K-feldspar, which nucleate around K-feldspar clasts in the ultramylonite (Fig. 5c). Thus, quartz aggregates are progressively disintegrated by dispersed feldspar with increasing strain. In addition, the formation of mixed-phase zones within clasts tails may be due to the nucleation of new phases (Fig. 5c; e.g. Kruse and Stünitz, 1999). These microstructures are in agreement with the increasing amount of grain contact between quartz and feldspar grains with increasing strain (Fig. 10). Phase nucleation is also consistent with the contrasted quartz LPO observed between quartz-rich layers and mixed-phase zones (Fig. 11). In these mixed phase zones, the quartz LPO is dispersed with respect to adjacent quartz-rich layers, which could be the result of enhanced nucleation in mixed-phase zones (Fig. 11). A similar process has been already documented in several experimental and natural studies to cause grain size reduction, loss of LPO and phases mixing (e.g. Kilian et al., 2011; Précigout and Stünitz, 2016; Cross and Skemer, 2017).

\subsubsection{Driving force for nucleation}

The formation of fine-grained polyphase assemblage by nucleation of new grains may be enhanced by chemical reactions (e.g. Stünitz and Tullis, 2001) and/or grain-boundary sliding (GBS; e.g. Linckens et al., 2014; Linckens et al., 2015). The nucleation of new grains with a different composition such as e.g. small and scattered white mica in dilatant sites may attest for intergranular fluid circulation (Fig. 3a-b; Fig. 4f; e.g. Oliot et al., 2014). The fluid circulation allows the transport of 
dissolved elements required for nucleation. In the case studied here, chemical variations - even small are systematically observed between the porphyroclasts and newly formed grains (Fig. 13). Thus, a purely mechanical phase mixing is considered as very unlikely because of these chemical variations, implying instead mass transfer via fluids. Element transport is manifested by the slight enrichment of $\mathrm{K}_{2} \mathrm{O}-\mathrm{P}_{2} \mathrm{O}_{5}-\mathrm{MgO}$ and depletion of $\mathrm{Na}_{2} \mathrm{O}$ with increasing strain (Fig. 12). All domains of the strain gradient from protolith to ultramylonite contain white mica. White mica porphyroclasts show quite homogeneous muscovite-rich composition, whereas fine-grained white mica is enriched in the $\mathrm{Mg}$ celadonite-component (phengite; Fig. 13). This gradient of reaction appears coeval with the investigated strain gradient and may explain the slight enrichment in $\mathrm{MgO}$ in the bulk composition. The enrichment of $\mathrm{K} 2 \mathrm{O}$ and depletion of $\mathrm{Na} 2 \mathrm{O}$ may be a result of the nucleation of new Or-rich, Kfeldspar and An-rich plagioclase with increasing strain. However, the variations in composition are too small to be interpreted with any level of confidence. Therefore, we suggest that the scale of mass transport is limited in order to maintain a quite homogeneous bulk composition, but it allows the local transport of elements required for chemically-driven nucleation.

To achieve the progressive breakdown of quartz aggregates with increasing strain by nucleation of new phases, GBS is an additional process that may be invoked. GBS is one important deformation mechanism that commonly combines with other mechanisms to deform any fine-grained mixed-phase zones (e.g. Raj and Ashby, 1971; Ashby and Verrall, 1973; Passchier and Trouw, 2005; Langdon, 2006; Warren and Hirth, 2006; Svahnberg and Piazolo, 2010; Miranda et al., 2016). When the displacement along grains is not fully accommodated, this may induce the opening of cavities into which the material can diffuse (e.g. Fliervoet et al., 1997; Fusseis et al., 2009; Kilian et al. 2011; Platt, 2015; Précigout and Stünitz, 2016; Précigout et al., 2017; Gilgannon et al., 2017). Nucleation of new grains in cavities inhibits grain growth and may promote the activity of grain size sensitive creep (e.g. Herwegh et al., 2011; Menegon et al., 2015; Gilgannon et al., 2017). In our case, several observations are consistent with a component of GBS during deformation and following nucleation in cavities, such as (1) the dispersion and weakening of pre-existing moderate LPO (Fig. 11; Jiang et al., 2000; Bestmann and Prior, 2003), (2) the relatively equant grain shape of quartz and K-feldspar (Fig. 7d-f; 
Passchier and Trouw, 2005), (3) the increase in mixing degree of quartz and feldspar grains with increasing strain due to e.g. phase nucleation (Fig. 10c; Kruse and Stünitz, 1999), and (4) the homogeneous mixing in the alternating fine-grained polymineralic layers of ultramylonite (Fig. 5a; Fliervoet et al., 1997) From the above, it is concluded that the main driving forces for nucleation are due to the combination of chemical reactions and grain-boundary sliding under the presence of fluids.

\subsection{Succession of deformation mechanisms and weakening processes}

\subsubsection{Evolution from protolith to protomylonite}

Increasing strain from protolith to protomylonite resulted in the development of an interconnected network of monophase layers of mica (Fig. 3c). The initial deformation of old magmatic mica grains by kinking, bending and recrystallization along the edges suggests a process of crystal plastic deformation (Holyoke and Tullis, 2006). This process combined with the nucleation of micas in cracks and along quartz grain boundaries may have promoted the interconnection of these weak phases in the protomylonite. The formation of a network of mica-bearing monophase layers have also been described in several granitic rocks deformed under greenschist to amphibolite facies conditions (Berthé et al., 1979; Gapais, 1989; Vernon et al., 2004; Johnson and Brown, 2004; Bukovská et al., 2016; Hunter et al., 2016, Wehrens et al., 2016, 2017) and is a major process for the weakening of the rock and the localization of deformation (e.g. Holyoke and Tullis, 2006; Menegon et al., 2008; Montési, 2013; Gardner et al., 2017). In addition, the reaction progress forming weak material as phengite in high-strain polyphase layers and ultramylonite is also expected to promote the localization of shear deformation, particularly when local grain size reduction in involved (Fig. 4a; e.g. Keller et al., 2004; Fossen and Cavalcante, 2017).

A recent study characterized the initiation and evolution of shear bands in the Questembert granite (Bukovská et al., 2016). According to their study, the formation of a network of mica shear bands is the main microstructural change responsible for weakening. Our observations show that the 
formation of a network of mica is only an early stage in the evolution, already achieved in low-strain mylonites (Fig. 8b-c). Following this stage, mylonites and ultramylonites are affected by a large decrease in grain size and increase in mixing zones (Fig. 4-5). These late stages of microstructural evolution and their rheological consequences are addressed hereafter.

\subsubsection{Evolution from protomylonite to ultramylonite}

\subsubsection{General features}

Increasing strain led to the formation of high-strain mylonite and ultramylonite characterized by the disintegration of most of large feldspar porphyroclasts and coarse-grained quartz-rich layers (Fig. 8e). This evolution results in the development of well-mixed fine-grained zones with a few preserved quartz-rich layers, forming alternating layers in the ultramylonite (Fig. 5-7). This is consistent with studies showing that in quartzo-feldspathic rocks deformed under greenschist facies conditions, mylonites and ultramylonites are composed largely of fine-grained mixed-phase zones (e.g. Stünitz and Fitz Gerald, 1993; Fliervoet et al., 1997). The fine-grained mixed-phase zones are commonly observed in the form of homogeneous mixing of all phases (e.g. Fitz Gerald and Stünitz, 1993; Fliervoet et al., 1997; Tsurumi et al., 2003), or in the form of alternating layers of fine-grained mixed-phase zones (e.g. Ree et al., 2005; Ishii et al., 2007). The geometrical organization of these zones in our study is close to the latter observations. Nevertheless, their compositions differ from published studies (Behrmann and Mainprice, 1987; Fitz Gerald and Stünitz, 1993; Fliervoet et al., 1997; Tsurumi et al., 2003; Ree et al., 2005; Ishii et al., 2007), where mixed zones are principally composed of plagioclase + K-feldspar with less proportion of quartz \pm mica \pm other minerals.

\subsubsection{Temporal sequence of protolith-protomylonite-mylonite-ultramylonite}


According to Augier et al. (2011), the most deformed ultramylonitic domain in the core of the shear zone presents locally less deformed rock portions that correspond to lower-strained domains. Identifying these relics of less deformed rocks suggest that the ultramylonite domains are the evolution, with increasing strain, of low-strain domains. An additional evidence in favour of this evolution with strain is revealed by CL-colors and textures. The pink feldspar grains and the dark blue/purple plagioclase porphyroclasts present in the ultramylonite are already observed as reaction rim products, in the protolith and protomylonite (Fig. 6). Furthermore, the homogeneous bulk rock composition (Table. 1; Fig.12) and the constant composition of the new nucleated phengites throughout the strain gradient (Fig. 13a) suggest that the protolith is identical in all strain facies. Consequently, high-strain domains (ultramylonite and mylonite) are interpreted as the evolution, with increasing strain, of low strain domains (protolith and protomylonites).

6.5.2.3. Preserved quartz-rich layers and fine-grained mixed zones in high-strain mylonite and ultramylonite

The well-developed SPO in the preserved quartz-rich layers in mylonite and ultramylonite, combined with the typical SGR recrystallization microstructures and the dominance of prism- $<\mathrm{a}\rangle$ and rhomb-<a $>$ active slip systems suggest dislocation creep as the dominant deformation mechanism (Fig. 11a-c; Passchier and Trouw, 2005). As indicated by the nearly random LPO of fine quartz grains at the rim of the layers, the quartz-rich layers are locally dismembered and incorporated in the polyphase mixed zones (Fig. 11a-c). Since we consider the ultramylonite and its fine-grained polyphase layers as the most evolved domains of the studied strain facies, the remaining quartz-rich layers in this domain must be considered as relics of an original mylonitic fabric before total disaggregation (e.g. Gilgannon et al., 2017). Although the quartz LPO in quartz-rich layers near the mixed zones is initially moderate, the evolution of the LPO fabric between these two domains suggests that during the disaggregation the quartz LPO dispersed (Fig. 11). 
The polyphase mixed zones are characterized by a very small grain size (Fig. 9b), a weaker LPO relative to quartz-rich layers (Fig. 11), a higher degree of phase mixing (Fig. 7-9), and an equant shape of quartz grains (Fig. 7). Based on these observations, we argue that deformation in the finegrained mixed-phase zones is dominated by grain size-sensitive (GSS) mechanisms, including a contribution of GBS (e.g. Behrmann and Mainprice, 1987; Rutter and Brodie, 1988; Olgaard, 1990; Linckens et al., 2011). GBS contributes to the dispersion of phases, reflected in their anticlustered distribution (Fig. 10c), the homogeneous mixing in the alternating layers (Fig. 5a), and to the weakening of the LPO in mixed-phase zones (Fig. 11; e.g. Behrmann and Mainprice, 1987; Stünitz and Fitz Gerald, 1993; Kilian et al., 2011). Some plagioclase clasts are also preserved and scattered throughout the microstructure in the ultramylonite (Fig. 5a-b). These plagioclases are characterized by a grain shape mostly rounded with convex grain boundaries, which is one evidence for a mechanically strong phase (e.g. Naziri et al., 1975; Stünitz and Fitz Gerald, 1993). Such microstructures are observed in the study of Lonka et al. (1998) and may reflect the progressive rotation of plagioclase clasts as rigid body in a ductile fine-grained zone during diffusion-accommodated GBS. The increase in GSS contribution to overall strain is in turn a weakening process (e.g. Boullier and Gueguen, 1975, Kerrich et al., 1980; De Bresser et al., 2001; Stünitz and Tullis, 2001; Menegon et al., 2015; Précigout and Stünitz, 2016) resulting in further strain localization in the deforming domain.

\section{Conclusions}

An evolution in microstructures and deformation mechanisms occurred across the different finite strain domains developed across the South Armorican Shear Zone in the Questembert granite. The microstructural, chemical and EBSD analyzes allow us to draw the following conclusions:

1. The transition from protolith to ultramylonite is associated with grain size reduction, which occurred by dynamic recrystallization, nucleation of grains with a different composition and fracturing. 
2. The transition from protolith to ultramylonite is also associated with a large increase in phase mixing. Phase mixing is mainly controlled by nucleation, whose driving force involves a combination of chemical reactions and grain-boundary sliding/dilatancy.

3. A reduced grain size may have triggered a transition in deformation mechanism with increasing strain. The quartz-rich layers, which display moderate LPO patterns, are deformed predominantly by dislocation creep, whereas the loss of LPO in polyphase fine-grained mixed zones, where strain has been strongly localized, suggests that diffusion creep and GBS became the dominant deformation mechanism. GBS is also highlighted by the occurrence of isolated K-feldspar grains located at triple junctions, and contributing to the dispersion of phases.

4. The early brittle deformation in low-strain domains, such as cracks in quartz aggregates, enhances fluid access and chemical reactions/nucleation to reduce grain size. A consequence of the formation of cracks and fluid-assisted nucleation is the interconnection of weak mica monophase layers in protomylonite.

5. With increasing strain, the mica-bearing layers evolve first into an interconnected network of fine-grained polyphase layers enriched in quartz and phengite in protomylonite and mylonite, and then by layers of fine-grained polyphase mixing composed of K-feldspar, quartz and phengite homogeneously mixed in mylonite and ultramylonite.

6. The strain weakening of the rock is a two-step process and the nature of the weak material, mica then fine-grained polyphase mixed zones that can deform by diffusion-accommodated grain boundary sliding, changes along with strain.

7. Although the pressure-temperature path of the shear zone is poorly constrained, the constant composition of the mica throughout the strain gradient suggests that the succession in weakening processes is not related to changing P-T conditions but to the accumulation of strain itself.

\section{Acknowledgments}


This work has received funding from (1) the European Research Council (ERC) under the seventh Framework Programme of the European Union (ERC Advanced Grant, grant agreement No 290864, RHEOLITH), and (2) the Labex VOLTAIRE (ANR-10-LABX-100-01). The authors are grateful to Renée Heilbronner and Holger Stünitz for their discussions and constructive comments, which contributed substantially to improve the manuscript. We also appreciate thorough and constructive reviews by Luca Menegon, Marco Herwegh and an anonymous reviewer. We would like to thank Rob Govers for editorial handling.

\section{Table captions}

Table. 1 Bulk rock chemical compositions of the four studied grades of deformation.

Table. 2 Representative chemical composition of K-feldspar, plagioclase and white mica between porphyroclast and grain in mixed zones.

\section{Figure captions}

Fig. 1. (a) Schematic map of the main domains forming the Armorican Massif, modified from Gumiaux et al., 2004. The studied area is delineated by the red rectangle. (b) Simplified geological map of the studied area modified from Augier et al., 2011. The location of the samples used is highlighted with colored dots. (c) Pictures of the samples used in this study, showing the different stages of deformation, from weakly deformed sample (domain 1) to the most deformed one (domain $5)$.

Fig. 2. (a) Quartz grains with polygonal to lobate grain boundaries. (b) Plagioclase porphyroclast with mechanical twinning and fractures filled by plagioclase (white arrows), and quartz aggregates crosscut by cracks filled with biotite (black arrows). (c) Crack filled with biotite crosscutting quartz aggregates (black arrows). (d) Rod-like cross-sections of white mica in the plagioclase. Also note that the 
plagioclase grain replaces that of the K-feldspar. (e) Large porphyroclast of K-feldspar showing the presence of oriented plagioclase exsolution. K-feldspar is progressively replaced by plagioclase grains (white arrows). All cross-polarized light micrographs. qtz: quartz, pl: plagioclase, kf: K-feldspar, wm: white mica, bt: biotite.

Fig. 3. (a-to-e) Cross-polarized light pictures showing the microstructures observed in protomylonite. (a) Small rod-like cross-sections of recrystallized white mica located at joints of two quartz grains. Note also the restricted growth of quartz by this white mica. Black arrow indicates the direction of growth. (b) Arrangement of small and oriented crystals of white mica (black arrows) in the quartz-rich layer, which define the foliation. (c) Thin monophase layers of mica crosscut quartz-rich layers and start to connect. (d) Connection of white micas through trails of very fine-grained white micas (black arrows). (e) Narrow zone of recrystallized grains forming polyphase layer composed principally of quartz and white mica. The latter are elongated preferentially parallel to the recrystallized zone margins. qtz: quartz, pl: plagioclase, kf: K-feldspar, wm: white mica, bt: biotite.

Fig. 4. (a-to-h) Coupled cross-polarized light micrographs, cathodoluminescence (CL) and SEM-BSE images representative of microstructures observed in mylonites. (a) Fine-grained polyphase layers (yellow dotted outline) rich in quartz and white mica, with locally few K-feldspar and plagioclase. (b) Close-up of the mixed-phase zone showing the partial interconnection of white micas intimately mixed with very fine-grained quartz grains. (c) Details of (b) showing the very fine-grained mixing composed at grain scale of quartz and white mica. (d) Polyphase layers rich in K-feldspar and quartz, with small quantities of white micas and plagioclase. (e) Grain size reduction of K-feldspar by nucleation in quartz essentially along grain boundaries and at triple junctions (black arrows). (f) Kfeldspar located in triple junction of quartz grains. (g) Irregular rim of plagioclase around a K-feldspar porphyroclast. (h) Quartz-rich layers strongly oriented, which show the development of subgrains (white arrows). (i) Small new quartz grains appearing along grain boundaries and within old grains (black arrows). qtz: quartz, pl: plagioclase, kf: K-feldspar, wm: white mica, ap: apatite. 
Fig. 5. (a-to-e) Coupled cathodoluminescence (CL) and SEM-BSE images representative of microstructures documented in ultramylonite. (a-b) Ultramylonite textures made of intercalated bands of fine-grained polymineralic layers. Clasts are white mica (black), albite (purple) and apatite (yellow), while the pink, dark brown and black colors are due to K-feldspar, quartz and white mica, respectively. (c) The tails of a K-feldspar clast are filled by K-feldspar and quartz. (d) Layers of variable composition with quartz-rich layers and fine-grained polyphase layers rich in quartz, Kfeldspar and white mica. Bigger plagioclase grains remain strong in form of clasts. (e) Close-up of the polyphase layers showing the thin white mica grains elongated subparallel to the lineation. qtz: quartz, pl: plagioclase, kf: K-feldspar, wm: white mica, ap: apatite.

Fig. 6. Cathodoluminescence (CL) images showing the evolution of feldspar microstructures with increasing strain. On CL images, quartz is dark blue-brown, initial K-feldspar is bright blue, new Kfeldspar is pink, white mica is black, initial plagioclase is brown and new plagioclase is dark blue/purple. qtz: quartz, pl: plagioclase, kf: K-feldspar, wm: white mica.

Fig. 7. (a-c-e) SEM-BSE images representative of the different type of mixed-phase zones and their respective manually digitized maps (b-d-f). Particle (PAROR) orientation of each phase is presented in a polar plot. (a) Mixed-phase zone rich in white mica and quartz, locally associated with K-feldspar and plagioclase. (c) Mixed-phase zone rich in K-feldspar, quartz, white mica, and minor plagioclase. (e) Mixed-phase zone similar to (c) with a higher proportion of white mica and where the quartz is the dominant phase. qtz: quartz, kf: K-feldspar, wm: white mica, ap: apatite.

Fig. 8. (a-to-e) Manually digitized maps of individual grains and phase mixing of each domain of studies are used as a basis for the quantitative microtextural analyzes. Mixed-phase zones develop in the mylonite and ultramylonite stage (domains 3 to 5), as an anastomosing network of fine-grained polyphase layers (in the mylonites) or as foliation-forming layers of fine-grained mixing (in the ultramylonite). Note that no distinction is made between K-feldspar and plagioclase for the first four domains; the yellow color refers to all types of feldspar. qtz: quartz, pl: plagioclase, kf: K-feldspar, wm: white mica. 
Fig. 9. Quartz grain size evolution. (a) The results are shown in box-and-whisker diagram. Individual boxes were limited by upper and lower quartiles, and within it the median was defined. This grain size evolution is obtained from cross-polarized light images, as the grain size is sufficiently large. (b) Evolution of quartz grain size between quartz-rich layers and mixed-phase zones for mylonite and ultramylonite. While mylonitic quartz grain size was determined using SEM-BSE images, we used the EBSD to document the grain size in the ultramylonitic domain.

Fig. 10. (a-to-c) Graphs showing the probability of contact between two phases, $Q=$ quartz and $\mathrm{F}=$ feldspar, for varying surface contact percentages of $\mathrm{Q}$ and $\mathrm{F}$. The results can be compared to the curves showing the theoretical values for random distribution $\mathrm{p}_{\mathrm{QQ}}(\mathbf{a}), \mathrm{p}_{\mathrm{FF}}(\mathbf{b})$ and $\mathrm{p}_{\mathrm{QF}}(\mathbf{c})$. (d) Examples of maps used for the GCF analysis. The maps of all boundaries, phase Q, phase F and contact surfaces between $\mathrm{Q}$ and $\mathrm{F}$ are successively represented.

Fig. 11. (a-to-d) Comparison of quartz c-axis [0001] and a-axis [11-20] preferred orientation, for both quartz-rich layers and mixed-phase zones, in mylonite (a-b) and ultramylonite (c-d). There is a systematic decrease in fabric strength (J-index and M-index) between the monomineralic quartz-rich layers and the fine-grained mixed-phase zones in both mylonite and ultramylonite. Related microstructures to these pole figures are also presented. The quartz-rich layers in both mylonite and ultramylonite show a preferred orientation of grains (a-c; black arrows). All images: BSE pictures. All pole figures in the upper hemisphere and equal area. qtz: quartz, pl: plagioclase, kf: K-feldspar, phg: phengite.

Fig. 12. Isocon diagram comparing the chemical composition of the protolith $\left(C^{0}\right)$ with those of protomylonite, mylonite and ultramylonite $\left(\mathrm{C}^{\mathrm{a}}\right)$. The blue line $\left(\mathrm{C}^{\mathrm{a}}=\mathrm{C}^{0}\right)$ represents the constant concentration, while the black lines represent $10 \%$ gains and $10 \%$ losses of components in $\mathrm{C}^{\mathrm{a}}$ compared to $\mathrm{C}^{0}$.

Fig. 13. (a-b-c) Chemical composition of white mica, plagioclase and K-feldspar. (a) CeladoniteMuscovite-Pyrophyllite ternary diagram shows composition of white mica grains from different stages 
of deformation. (b-c) Albite-Orthoclase-Anorthite combined ternary diagram for both plagioclase and $\mathrm{K}$-feldspar composition is also presented for different stages of deformation.

Fig. 14. (a) P-T pseudosection calculated in the CNKFMASH system with the following solution models: Ti-Fe-Mg-Mn-biotite with compound formation (Powell and Holland, 1999), white mica (Coggon and Holland, 2002; Auzanneau et al., 2010), feldspar (Holland and Powell, 2003), and chlorite (Holland et al., 1998). Isopleth plots of the amount of chlorite, clinozoisite and biotite are also superimposed. (b) Representation of $\mathrm{Si}$ and $\mathrm{X}_{\mathrm{Mg}}$ content in white mica isopleth plots and the compositional isopleths of anorthite components in plagioclase. The blue area represents the intersection of the compositional isopleths of $\mathrm{Si}$ and $\mathrm{XMg}$ in white mica and anorthite components in plagioclase.

\section{References}

Ashby, M.., Verrall, R.., 1973. Diffusion-accommodated flow and superplasticity. Acta Metall. 21, 149-163. doi:10.1016/0001-6160(73)90057-6

Augier, R., Choulet, F., Faure, M., Turrillot, P., 2015. A turning-point in the evolution of the Variscan orogen: the ca. 325 Ma regional partial-melting event of the coastal South Armorican domain (South Brittany and Vendée, France). Bull. la Société Géologique Fr. 186, 63-91. doi:10.2113/gssgfbull.186.2-3.63

Augier, R., Menier, D., Vliet-Lanoë, B. Van, Hallégouet, B., Chauris, L., Turrillot, P., Carn, A., Thinon, I., 2011. Notice de la carte géologique de France au 1/50000: feuille de Vannes St GILDAS-DE-RHUIS Feuille 417.

Auzanneau, E., Schmidt, M.W., Vielzeuf, D., D Connolly, J.A., 2010. Titanium in phengite: a geobarometer for high temperature eclogites. Contrib. to Mineral. Petrol. 159, 1-24. doi:10.1007/s00410-009-0412-7

Ballèvre, M., Bosse, V., Ducassou, C., Pitra, P., 2009. Palaeozoic history of the Armorican Massif: 
Models for the tectonic evolution of the suture zones. Comptes Rendus - Geosci. 341, 174-201. doi:10.1016/j.crte.2008.11.009

Ballèvre, M., Marchand, J., Godard, G., Goujou, J.-C., Christian, J., Wyns, R., 1994. Eo-Hercynian Events in the Armorican Massif, in: Pre-Mesozoic Geology in France and Related Areas. Springer Berlin Heidelberg, Berlin, Heidelberg, pp. 183-194. doi:10.1007/978-3-642-849152_19

Behrmann, J.H., 1985. Crystal plasticity and superplasticity in quartzite; A natural example. Tectonophysics 115, 101-129. doi:10.1016/0040-1951(85)90102-7

Behrmann, J.H., Mainprice, D., 1987. Deformation mechanisms in a high-temperature quartz-feldspar mylonite: evidence for superplastic flow in the lower continental crust. Tectonophysics 140, 297-305. doi:10.1016/0040-1951(87)90236-8

Berthé, D., Choukroune, P., Jegouzo, P., 1979. Orthogneiss, mylonite and non coaxial deformation of granites: the example of the South Armorican Shear Zone. J. Struct. Geol. 1, 31-42. doi:10.1016/0191-8141(79)90019-1

Bestmann, M., Prior, D.J., 2003. Intragranular dynamic recrystallization in naturally deformed calcite marble: Diffusion accommodated grain boundary sliding as a result of subgrain rotation recrystallization. J. Struct. Geol. 25, 1597-1613. doi:10.1016/S0191-8141(03)00006-3

Bosse, V., Feraud, G., Ruffet, G., Ballèvre, M., Peucat, J.-J., De Jong, K., 2000. Late Devonian subduction and early-orogenic exhumation of eclogite-facies rocks from the Champtoceaux Complex (Variscan belt, France). Geol. J. 35, 297-325. doi:10.1002/gj.864

Bouchez, J.L., Delas, C., Gleizes, G., Nédélec, A., Cuney, M., 1992. Submagmatic microfractures in granites. Geology 20, 35. doi:10.1130/0091-7613(1992)020<0035:SMIG>2.3.CO;2

Boullier, A.M., Gueguen, Y., 1975. SP-Mylonites: Origin of some mylonites by superplastic flow. Contrib. to Mineral. Petrol. 50, 93-104. doi:10.1007/BF00373329

Brodhag, S.H., Herwegh, M., 2010. The effect of different second-phase particle regimes on grain 
growth in two-phase aggregates: Insights from in situ rock analogue experiments. Contrib. to Mineral. Petrol. 160, 219-238. doi:10.1007/s00410-009-0474-6

Brown, M., Dallmeyer, R.D., 1996. Rapid Variscan exhumation and the role of magma in core complex formation: southern Brittany metamorphic belt, France. J. Metamorph. Geol. 14, 361379. doi:10.1111/j.1525-1314.1996.00361.x

Bukovská, Z., Jeřábek, P., Morales, L.F.G., 2016. Major softening at brittle-ductile transition due to interplay between chemical and deformation processes: An insight from evolution of shear bands in the South Armorican Shear Zone. J. Geophys. Res. Solid Earth 121, 1158-1182. doi:10.1002/2015JB012319

Bunge, H., 1982. Texture Analysis in Materials Science: Mathematical Models. Butterworths, London. $593 \mathrm{pp}$.

Cartier, C., Faure, M., 2004. The Saint-Georges-sur-Loire olistostrome, a key zone to understand the Gondwana-Armorica boundary in the Variscan belt (Southern Brittany, France). Int. J. Earth Sci. 93, 945-958. doi:10.1007/s00531-004-0398-3

Coggon, R., Holland, T., 2002. Mixing properties of phengitic micas and revised garnet-phengite thermobarometers. J. Metamorph. Geol. 20, 683-696. doi:10.1046/j.1525-1314.2002.00395.x

Cogne, J., 1960. Metamorphismes et granitisations en liaison avec l'evolution orogenique en Bretagne meridionale. Bull. la Société Géologique Fr. S7-II. doi:10.2113/gssgfbull.S7-II.2.213

Connolly, J.A.D., 2005. Computation of phase equilibria by linear programming: A tool for geodynamic modeling and its application to subduction zone decarbonation. Earth Planet. Sci. Lett. 236, 524-541. doi:10.1016/J.EPSL.2005.04.033

Cross, A.J., Skemer, P., 2017. Ultramylonite generation via phase mixing in high-strain experiments. J. Geophys. Res. Solid Earth 122, 1744-1759. doi:10.1002/2016JB013801

De Bresser, J.H.P., Peach, C.J., Reijs, J.P.J., Spiers, C.J., 1998. On dynamic recrystallization during solid state flow: Effects of stress and temperature. Geophys. Res. Lett. 25, 3457-3460. 
doi:10.1029/98GL02690

De Bresser, J.H.P., Ter Heege, J.H., Spiers, C.J., 2001. Grain size reduction by dynamic recrystallization: Can it result in major rheological weakening? Int. J. Earth Sci. 90, 28-45. doi:10.1007/s005310000149

de Ronde, A.A., Stünitz, H., Tullis, J., Heilbronner, R., 2005. Reaction-induced weakening of $\begin{array}{llll}\text { plagioclase-olivine } & \text { composites. } & \text { Tectonophysics } & 409,\end{array}$ doi:10.1016/J.TECTO.2005.08.008

Dell'Angelo, L.N., Tullis, J., 1996. Textural and mechanical evolution with progressive strain in experimentally deformed aplite. Tectonophysics 256, 57-82. doi:10.1016/0040-1951(95)00166-2

Dijkstra, A., Drury, M., Vissers, R., Newman, J., 2002. On the role of melt-rock reaction in mantle shear zone formation in the Othris Peridotite Massif (Greece). J. Struct. Geol. 24, 1431-1450. doi:10.1016/S0191-8141(01)00142-0

Drury, M.R., Urai, J.L., 1990. Deformation-related recrystallization processes. Tectonophysics 172, 235-253. doi:10.1016/0040-1951(90)90033-5

Etheridge, M.A., Wilkie, J.C., 1979. Grainsize reduction, grain boundary sliding and the flow strength of mylonites. Tectonophysics 58, 159-178. doi:10.1016/0040-1951(79)90327-5

Faure, M., Bé Mézème, E., Cocherie, A., Rossi, P., Chemenda, A., Boutelier, D., 2008. Devonian geodynamic evolution of the Variscan Belt, insights from the French Massif Central and Massif Armoricain. Tectonics 27, TC2005. doi:10.1029/2007TC002115

Faure, M., Bé Mézème, E., Duguet, M., Cartier, C., Talbot, J.Y., 2005. Paleozoic tectonic evolution of medio-Europa from the example of the French Massif Central and Massif Armoricain. J. Virtual Explor. 19. doi:10.3809/jvirtex.2005.00120

Fitz Gerald, J., Stünitz, H., 1993. Deformation of granitoids at low metamorphic grade. I: Reactions and grain size reduction. Elsevier Sci. Publ. B.V 221, 269-297. doi:10.1016/00401951(93)90164-F 
Fliervoet, T.F., White, S.H., 1995. Quartz deformation in a very fine grained quartzo-feldspathic mylonite: a lack of evidence for dominant grain boundary sliding deformation. J. Struct. Geol. 17, 1095-1109. doi:10.1016/0191-8141(95)00007-Z

Fliervoet, T.F., White, S.H., Drury, M.R., 1997. Evidence for dominant grain-boundary sliding deformation in greenschist- and amphibolite-grade polymineralic ultramylonites from the Redbank Deformed Zone, Central Australia. J. Struct. Geol. 19, 1495-1520. doi:10.1016/S01918141(97)00076-X

Fossen, H., Cavalcante, G.C.G., 2017. Shear zones - A review. Earth-Science Rev. 171, 434-455. doi:10.1016/J.EARSCIREV.2017.05.002

Fusseis, F., Handy, M.R., 2008. Micromechanisms of shear zone propagation at the brittle-viscous transition. J. Struct. Geol. 30, 1242-1253. doi:10.1016/J.JSG.2008.06.005

Fusseis, F., Regenauer-Lieb, K., Liu, J., Hough, R.M., De Carlo, F., 2009. Creep cavitation can establish a dynamic granular fluid pump in ductile shear zones. Nature 459, 974-977. doi:10.1038/nature08051

Gapais, D., 1989. Shear structures within deformed granites: mechanical and thermal indicators. Geology 17, 1144-1147. doi:10.1130/0091-7613(1989)017<1144:SSWDGM>2.3.CO

Gapais, D., White, S.H., 1982. Ductile Shear Bands in a Naturally Deformed Quartzite. Textures Microstruct. 5, 1-17. doi:10.1155/TSM.5.1

Gardner, R., Piazolo, S., Evans, L., Daczko, N., 2017. Patterns of strain localization in heterogeneous, polycrystalline rocks - a numerical perspective. Earth Planet. Sci. Lett. 463, 253-265. doi:10.1016/j.eps1.2017.01.039

Gilgannon, J., Fusseis, F., Menegon, L., Regenauer-Lieb, K., Buckman, J., 2017. Hierarchical creep cavity formation in an ultramylonite and implications for phase mixing. Solid Earth 85194, 1193-1209. doi:10.5194/se-8-1193-2017

Grant, J.A., 1986. The isocon diagram; a simple solution to Gresens' equation for metasomatic 
alteration. Econ. Geol. 81, 1976-1982. doi:10.2113/gsecongeo.81.8.1976

Gumiaux, C., Gapais, D., Brun, J.P., Chantraine, J., Ruffet, G., 2004. Tectonic history of the Hercynian Armorican shear belt (Brittany, France). Geodin. Acta 17, 289-307. doi:10.3166/ga.17.289-307

Handy, M.R., 1990. The solid-state flow of polymineralic rocks. J. Geophys. Res. 95, 8647. doi:10.1029/JB095iB06p08647

Heilbronner, R., Barrett, S., 2014. Spatial Distributions, in: Image Analysis in Earth Sciences. Springer Berlin Heidelberg, Berlin, Heidelberg, pp. 351-368. doi:10.1007/978-3-642-10343-8_1

Herwegh, M., Berger, A., 2004. Deformation mechanisms in second-phase affected microstructures and their energy balance. J. Struct. Geol. 26, 1483-1498. doi:10.1016/J.JSG.2003.10.006

Herwegh, M., Jenni, A., 2001. Granular flow in polymineralic rocks bearing sheet silicates: New evidence from natural examples. Tectonophysics 332, 309-320. doi:10.1016/S00401951(00)00288-2

Herwegh, M., Linckens, J., Ebert, A., Berger, A., Brodhag, S.H., 2011. The role of second phases for controlling microstructural evolution in polymineralic rocks: A review. J. Struct. Geol. 33, 1728 1750. doi:10.1016/j.jsg.2011.08.011

Hippertt, J., 1998. Breakdown of feldspar, volume gain and lateral mass transfer during mylonitization of granitoid in a low metamorphic grade shear zone. J. Struct. Geol. 20, 175-193. doi:10.1016/S0191-8141(97)00083-7

Hippler, S.J., Knipe, R.J., 1990. The evolution of cataclastic fault rocks from a pre-existing mylonite. Geol. Soc. London, Spec. Publ. 54, 71-79. doi:10.1144/GSL.SP.1990.054.01.08

Hirth, G., Tullis, J., 1992. Dislocation creep regimes in quartz aggregates. J. Struct. Geol. 14, 145159. doi:10.1016/0191-8141(92)90053-Y

Holland, T., Baker, J., Powell, R., 1998. Mixing properties and activity-composition relationships of chlorites in the system MgO-FeO-Al2O3-SiO2-H2O. Eur. J. Mineral. 10, 395-406. 
doi:10.1127/ejm/10/3/0395

Holland, T., Powell, R., 2004. An internally consistent thermodynamic data set for phases of petrological interest. J. Metamorph. Geol. 16, 309-343. doi:10.1111/j.1525-1314.1998.00140.x

Holland, T., Powell, R., 2003. Activity-composition relations for phases in petrological calculations: an asymmetric multicomponent formulation. Contrib. to Mineral. Petrol. 145, 492-501. doi:10.1007/s00410-003-0464-z

Holyoke, C.W., Tullis, J., 2006. Mechanisms of weak phase interconnection and the effects of phase strength contrast on fabric development. J. Struct. Geol. 28, 621-640. doi:10.1016/j.jsg.2006.01.008

Hunter, N.J.R., Hasalová, P., Weinberg, R.F., Wilson, C.J.L., 2016. Fabric controls on strain accommodation in naturally deformed mylonites: The influence of interconnected micaceous layers. J. Struct. Geol. 83, 180-193. doi:10.1016/j.jsg.2015.12.005

Ishii, K., Kanagawa, K., Shigematsu, N., Okudaira, T., 2007. High ductility of K-feldspar and development of granitic banded ultramylonite in the Ryoke metamorphic belt, SW Japan. J. Struct. Geol. 29, 1083-1098. doi:10.1016/j.jsg.2007.02.008

Jégouzo, P., 1980. The South Armorican Shear Zone. J. Struct. Geol. 2, 39-47. doi:10.1016/0191$8141(80) 90032-2$

Jiang, Z., Prior, D.J., Wheeler, J., 2000. Albite crystallographic preferred orientation and grain misorientation distribution in a low-grade mylonite: implications for granular flow. J. Struct. Geol. 22, 1663-1674. doi:10.1016/S0191-8141(00)00079-1

Johnson, T., Brown, M., 2004. Quantitative constraints on metamorphism in the Variscides of southern Brittany - A complementary pseudosection approach. J. Petrol. 45, 1237-1259. doi:10.1093/petrology/egh012

Jordan, P., 1988. The rheology of polymineralic rocks - an approach. Geol. Rundschau 77, 285-294. doi:10.1007/BF01848690 
Keller, L.M., Abart, R., Stünitz, H., De Capitani, C., 2004. Deformation, mass transfer and mineral reactions in an eclogite facies shear zone in a polymetamorphic metapelite (Monte Rosa nappe, western Alps). J. Metamorph. Geol. 22, 97-118. doi:10.1111/j.1525-1314.2004.00500.x

Kenkmann, T., Dresen, G., 2002. Dislocation microstructure and phase distribution in a lower crustal shear zone - An example from the Ivrea-Zone, Italy. Int. J. Earth Sci. 91, 445-458. doi:10.1007/s00531-001-0236-9

Kerrich, R., Allison, I., Barnett, R.L., Moss, S., Starkey, J., 1980. Microstructural and chemical transformations accompanying deformation of granite in a shear zone at Miéville, Switzerland; with implications for stress corrosion cracking and superplastic flow. Contrib. to Mineral. Petrol. 73, 221-242. doi:10.1007/BF00381442

Kilian, R., Heilbronner, R., Stünitz, H., 2011. Quartz grain size reduction in a granitoid rock and the transition from dislocation to diffusion creep. J. Struct. Geol. 33, 1265-1284. doi:10.1016/j.jsg.2011.05.004

Kruhl, J., Erdmann, S., Büttner, S., 2007. Brittle-ductile microfabrics in naturally deformed cordierite: Evidence for significant short-term strain-rate variations. J. Struct. Geol. 29, 355-374. doi:10.1016/J.JSG.2006.09.002

Kruse, R., Stünitz, H., 1999. Deformation mechanisms and phase distribution in mafic hightemperature mylonites from the Jotun Nappe, southern Norway. Tectonophysics 303, 223-249. doi:10.1016/S0040-1951(98)00255-8

Langdon, T.G., 2006. Grain boundary sliding revisited: Developments in sliding over four decades. J. Mater. Sci. 41, 597-609. doi:10.1007/s10853-006-6476-0

Linckens, J., Bruijn, R.H.C., Skemer, P., 2014. Dynamic recrystallization and phase mixing in experimentally deformed peridotite. Earth Planet. Sci. Lett. 388, 134-142. doi:10.1016/j.eps1.2013.11.037

Linckens, J., Herwegh, M., Mntener, O., Mercolli, I., 2011. Evolution of a polymineralic mantle shear 
zone and the role of second phases in the localization of deformation. J. Geophys. Res. Solid Earth 116, 1-21. doi:10.1029/2010JB008119

Linckens, J., Herwegh, M., Müntener, O., 2015. Small quantity but large effect - How minor phases control strain localization in upper mantle shear zones. Tectonophysics 643, 26-43. doi:10.1016/j.tecto.2014.12.008

Lonka, H., Schulmann, K., Venera, Z., 1998. Ductile deformation of tonalite in the Suomusjärvi shear zone,south-western Finland. J. Struct. Geol. 20, 783-798. doi:10.1016/s0191-8141(98)00003-0

Matte, P., 2001. The Variscan collage and orogeny (480-290 Ma) and the tectonic definition of the Armorica microplate: a review. Terra Nov. 13, 122-128. doi:10.1046/j.1365-3121.2001.00327.x

Matte, P., 1991. Accretionary history and crustal evolution of the Variscan belt in Western Europe. Tectonophysics 196, 309-337. doi:10.1016/0040-1951(91)90328-P

Matte, P., 1986. Tectonics and plate tectonics model for the Variscan belt of Europe. Tectonophysics 126, 329-374. doi:10.1016/0040-1951(86)90237-4

Menegon, L., Fusseis, F., Stunitz, H., Xiao, X., O., L., J.-P., B., 2015. Creep cavitation bands control porosity and fluid flow in lower crustal shear zones. Geology 43, 227-230. doi:10.1130/G36307.1

Menegon, L., Pennacchioni, G., Spiess, R., 2008. Dissolution-precipitation creep of K-feldspar in midcrustal granite mylonites. J. Struct. Geol. 30, 565-579. doi:10.1016/j.jsg.2008.02.001

Menegon, L., Pennacchioni, G., Stünitz, H., 2006. Nucleation and growth of myrmekite during ductile shear deformation in metagranites. J. Metamorph. Geol. 24, 553-568. doi:10.1111/j.15251314.2006.00654.x

Miranda, E.A., Hirth, G., John, B.E., 2016. Microstructural evidence for the transition from dislocation creep to dislocation-accommodated grain boundary sliding in naturally deformed plagioclase. J. Struct. Geol. 92, 30-45. doi:10.1016/j.jsg.2016.09.002

Montési, L.G.J., 2013. Fabric development as the key for forming ductile shear zones and enabling 
plate tectonics. J. Struct. Geol. 50, 254-266. doi:10.1016/j.jsg.2012.12.011

Montési, L.G.J., Hirth, G., 2003. Grain size evolution and the rheology of ductile shear zones: from laboratory experiments to postseismic creep. Earth Planet. Sci. Lett. 211, 97-110. doi:10.1016/S0012-821X(03)00196-1

Naziri, H., Pearce, R., Brown, M.H., Hale, K.F., 1975. Microstructural-mechanism relationship in the zinc/ aluminium eutectoid superplastic alloy. Acta Metall. 23, 489-496. doi:10.1016/00016160(75)90088-7

Olgaard, D.L., 1990. The role of second phase in localizing deformation. Geol. Soc. London, Spec. Publ. 54, 175-181. doi:10.1144/GSL.SP.1990.054.01.17

Oliot, E., Goncalves, P., Schulmann, K., Marquer, D., Lexa, O., 2014. Mid-crustal shear zone formation in granitic rocks: Constraints from quantitative textural and crystallographic preferred orientations analyses. Tectonophysics 612-613,63-80. doi:10.1016/j.tecto.2013.11.032

Panozzo, R., 1983. Two-dimensional analysis of shape-fabric using projections of digitized lines in a plane. Tectonophysics 95, 279-294. doi:10.1016/0040-1951(83)90073-2

Passchier, C., 1984. The generation of ductile and brittle shear bands in a low-angle mylonite zone. J. Struct. Geol. 6, 273-281. doi:10.1016/0191-8141(84)90051-8

Passchier, C., Trouw, R.A.J., 2005. Deformation Mechanisms, in: Microtectonics. Springer-Verlag, Berlin/Heidelberg, pp. 25-66. doi:10.1007/3-540-29359-0_3

Platt, J.P., 2015. Rheology of two-phase systems: A microphysical and observational approach. J. Struct. Geol. 77, 213-227. doi:10.1016/j.jsg.2015.05.003

Poirier, J.P., 1980. Shear localization and shear instability in materials in the ductile field. J. Struct. Geol. 2, 135-142. doi:10.1016/0191-8141(80)90043-7

Powell, R., Holland, T., 1999. Relating formulations of the thermodynamics of mineral solid solutions; activity modeling of pyroxenes, amphiboles, and micas. Am. Mineral. 84, 1-14. doi:10.2138/am1999-1-201 
Précigout, J., Gueydan, F., Gapais, D., Garrido, C.J., Essaifi, A., 2007. Strain localisation in the subcontinental mantle - a ductile alternative to the brittle mantle. Tectonophysics 445,318 336. doi:10.1016/J.TECTO.2007.09.002

Précigout, J., Prigent, C., Palasse, L., Pochon, A., 2017. Water pumping in mantle shear zones. Nat. Commun. 8, 15736. doi:10.1038/ncomms 15736

Précigout, J., Stünitz, H., 2016. Evidence of phase nucleation during olivine diffusion creep: A new perspective for mantle strain localisation. Earth Planet. Sci. Lett. 455, 94-105. doi:10.1016/j.eps1.2016.09.029

Raimbourg, H., Toyoshima, T., Harima, Y., Kimura, G., 2008. Grain-size reduction mechanisms and rheological consequences in high-temperature gabbro mylonites of Hidaka, Japan. Earth Planet. Sci. Lett. 267, 637-653. doi:10.1016/j.eps1.2007.12.012

Raj, R., Ashby, M.F., 1971. On grain boundary sliding and diffusional creep. Metall. Trans. 2, 11131127. doi:10.1007/BF02664244

Ree, J.H., Kim, H.S., Han, R., Jung, H., 2005. Grain-size reduction of feldspars by fracturing and neocrystallization in a low-grade granitic mylonite and its rheological effect. Tectonophysics 407, 227-237. doi:10.1016/j.tecto.2005.07.010

Rutter, E.H., Brodie, K.H., 1988. The role of tectonic grain size reduction in the rheological stratification of the lithosphere. Geol. Rundschau 77, 295-307. doi:10.1007/BF01848691

Shea, W.T., Kronenberg, A.K., 1993. Strength and anisotropy of foliated rocks with varied mica contents. J. Struct. Geol. 15, 1097-1121. doi:10.1016/0191-8141(93)90158-7

Simpson, C., Wintsch, R.P., 1989. Evidence for deformation-induced K-feldspar replacement by myrmekite. J. Metamorph. Geol. 7, 261-275. doi:10.1111/j.1525-1314.1989.tb00588.x

Skemer, P., Katayama, I., Jiang, Z., Karato, S., 2005. The misorientation index: Development of a new method for calculating the strength of lattice-preferred orientation. Tectonophysics $411,157-$ 167. doi:10.1016/J.TECTO.2005.08.023 
Song, W.J., Ree, J.H., 2007. Effect of mica on the grain size of dynamically recrystallized quartz in a quartz-muscovite mylonite. J. Struct. Geol. 29, 1872-1881. doi:10.1016/j.jsg.2007.09.011

Stewart, M., Holdsworth, R.E., Strachan, R.A., 2000. Deformation processes and weakening mechanisms within the frictional-viscous transition zone of major crustal-scale faults: insights from the Great Glen Fault Zone, Scotland. J. Struct. Geol. 22, 543-560. doi:10.1016/S01918141(99)00164-9

Stipp, M., Stünitz, H., Heilbronner, R., Schmid, S.M., 2002. The eastern Tonale fault zone: a "natural laboratory" for crystal plastic deformation of quartz over a temperature range from 250 to $700^{\circ} \mathrm{C}$. J. Struct. Geol. 24, 1861-1884. doi:10.1016/S0191-8141(02)00035-4

Stünitz, H., Fitz Gerald, J.D., 1993. Deformation of granitoids at low metamorphic grades: II. Granular flow in albite rich mylonites. Tectonophysics 221, 299-324. doi:10.1016/00401951(93)90164-F

Stünitz, H., Fitz Gerald, J.D., Tullis, J., 2003. Dislocation generation, slip systems, and dynamic recrystallization in experimentally deformed plagioclase single crystals. Tectonophysics 372, 215-233. doi:10.1016/S0040-1951(03)00241-5

Stünitz, H., Tullis, J., 2001. Weakening and strain localization produced by syn-deformational reaction of plagioclase. Int. J. Earth Sci. 90, 136-148. doi:10.1007/s005310000148

Svahnberg, H., Piazolo, S., 2010. The initiation of strain localisation in plagioclase-rich rocks: Insights from detailed microstructural analyses. J. Struct. Geol. 32, 1404-1416. doi:10.1016/j.jsg.2010.06.011

Tartèse, R., Boulvais, P., 2010. Differentiation of peraluminous leucogranites "en route" to the surface. Lithos 114, 353-368. doi:10.1016/j.lithos.2009.09.011

Tartèse, R., Boulvais, P., Poujol, M., Chevalier, T., Paquette, J.L., Ireland, T.R., Deloule, E., 2012. Mylonites of the South Armorican Shear Zone: Insights for crustal-scale fluid flow and waterrock interaction processes. J. Geodyn. 56-57, 86-107. doi:10.1016/j.jog.2011.05.003 
Tartèse, R., Boulvais, P., Poujol, M., Vigneresse, J.-L., 2011. Granite petrogenesis revealed by combined gravimetric and radiometric imaging. Tectonophysics 501, 98-103. doi:10.1016/J.TECTO.2011.02.003

Tsurumi, J., Hosonuma, H., Kanagawa, K., 2003. Strain localization due to a positive feedback of deformation and myrmekite-forming reaction in granite and aplite mylonites along the Hatagawa Shear Zone of NE Japan. J. Struct. Geol. 25, 557-574. doi:10.1016/S0191-8141(02)00048-2

Tullis, J., Wenk, H.R., 1994. Effect of muscovite on the strength and lattice preferred orientations of experimentally deformed quartz aggregates. Mater. Sci. Eng. A 175, 209-220. doi:10.1016/09215093(94)91060-X

Turrillot, P., Augier, R., Faure, M., 2009. The top-to-the-southeast Sarzeau shear zone and its place in the late-orogenic extensional tectonics of southern Armorica. Bull. la Soc. Geol. Fr. 180, 247261. doi:10.2113/gssgfbull.180.3.247

Turrillot, P., Augier, R., Monié, P., Faure, M., 2011. Late orogenic exhumation of the Variscan highgrade units (South Armorican Domain, western France), combined structural and ${ }^{40} \mathrm{Ar} /{ }^{39} \mathrm{Ar}$ constraints. Tectonics 30, n/a-n/a. doi:10.1029/2010TC002788

Turrillot, P., Faure, M., Martelet, G., Chen, Y., Augier, R., 2011. Pluton-dyke relationships in a Variscan granitic complex from AMS and gravity modelling. Inception of the extensional tectonics in the South Armorican Domain (France). J. Struct. Geol. 33, 1681-1698. doi:10.1016/J.JSG.2011.08.004

Vernon, R.H., Johnson, S.E., Melis, E.A., 2004. Emplacement-related microstructures in the margin of a deformed pluton: the San José tonalite, Baja California, México. J. Struct. Geol. 26, 18671884. doi:10.1016/J.JSG.2004.02.007

Viegas, G., Menegon, L., Archanjo, C., 2016. Brittle grain-size reduction of feldspar, phase mixing and strain localization in granitoids at mid-crustal conditions (Pernambuco shear zone, NE Brazil). Solid Earth 7, 375-396. doi:10.5194/se-7-375-2016 
Vigneresse, J.-L., Brun, J.-P., 1983. Les leucogranites armoricains marqueurs de la deformation regionale; apport de la gravimetrie. Bull. la Société Géologique Fr. S7-XXV. doi:10.2113/gssgfbull.S7-XXV.3.357

Warren, J.M., Hirth, G., 2006. Grain size sensitive deformation mechanisms in naturally deformed peridotites. Earth Planet. Sci. Lett. 248, 423-435. doi:10.1016/j.eps1.2006.06.006

Watts, M.J., Williams, G.D., 1979. Fault rocks as indicators of progressive shear deformation in the Guingamp region, Brittany. J. Struct. Geol. 1, 323-332. doi:10.1016/0191-8141(79)90007-5

Wehrens, P., Baumberger, R., Berger, A., Herwegh, M., 2017. How is strain localized in a metagranitoid, mid-crustal basement section? Spatial distribution of deformation in the central Aar massif (Switzerland). J. Struct. Geol. 94, 47-67. doi:10.1016/J.JSG.2016.11.004

Wehrens, P., Berger, A., Peters, M., Spillmann, T., Herwegh, M., 2016. Deformation at the frictionalviscous transition: Evidence for cycles of fluid-assisted embrittlement and ductile deformation in the granitoid crust. Tectonophysics 693, 66-84. doi:10.1016/J.TECTO.2016.10.022

White, S.H., Burrows, S.E., Carreras, J., Shaw, N.D., Humphreys, F.J., 1980. On mylonites in ductile shear zones. J. Struct. Geol. 2, 175-187. doi:10.1016/0191-8141(80)90048-6 
Table. 1 Bulk rock chemical compositions of the four studied grades of deformation

\begin{tabular}{ccccc}
\hline \hline Sample type & Protolith & Protomylonite & Mylonite & Ultramylonite \\
\hline $\mathrm{Wt} \%$ oxide & & & & \\
$\mathrm{SiO}_{2}$ & 75.57 & 73.88 & 72.95 & 74.37 \\
$\mathrm{TiO}_{2}$ & 0.11 & 0.08 & 0.18 & 0.13 \\
$\mathrm{Al}_{2} \mathrm{O}_{3}$ & 14.29 & 14.94 & 15.39 & 14.96 \\
$\mathrm{Fe}_{2} \mathrm{O}_{3}$ & 0.81 & 0.89 & 0.79 & 0.78 \\
$\mathrm{MnO}$ & 0.02 & 0.03 & 0.01 & 0.01 \\
$\mathrm{MgO}$ & 0.18 & 0.19 & 0.20 & 0.21 \\
$\mathrm{CaO}$ & 0.53 & 0.61 & 0.47 & 0.53 \\
$\mathrm{Na} 2 \mathrm{O}$ & 3.37 & 3.65 & 2.96 & 2.69 \\
$\mathrm{~K}_{2} \mathrm{O}$ & 4.43 & 4.40 & 5.08 & 5.30 \\
$\mathrm{P}_{2} \mathrm{O}_{5}$ & 0.39 & 0.37 & 0.48 & 0.50 \\
$\mathrm{Total}$ & 99.70 & 99.04 & 98.51 & 99.48 \\
\hline $\mathrm{Molar} \mathrm{content}$ & & & & \\
$\mathrm{SiO}_{2}$ & 1.2577 & 1.2296 & 1.2141 & 1.2378 \\
$\mathrm{TiO}_{2}$ & 0.0014 & 0.0011 & 0.0023 & 0.0016 \\
$\mathrm{Al}_{2} \mathrm{O}_{3}$ & 0.1402 & 0.1465 & 0.1509 & 0.1467 \\
$\mathrm{Fe}_{2} \mathrm{O}_{3}$ & 0.0051 & 0.0056 & 0.0049 & 0.0049 \\
$\mathrm{MnO}_{\mathrm{MgO}}$ & 0.0002 & 0.0004 & 0.0001 & 0.0001 \\
$\mathrm{CaO}_{\mathrm{Total}}$ & 0.0045 & 0.0047 & 0.0050 & 0.0052 \\
$\mathrm{P}_{2} \mathrm{O}_{5}$ & 0.0095 & 0.0109 & 0.0084 & 0.0095 \\
$\mathrm{Na}_{2} \mathrm{O}$ & 0.0544 & 0.0589 & 0.0478 & 0.0434 \\
\hline \hline
\end{tabular}


Table. 2 Representative chemical composition of K-feldspar, plagioclase and white mica between porphyroclast and grain in mixed zones

\begin{tabular}{|c|c|c|c|c|c|c|c|c|}
\hline \multirow[b]{2}{*}{ Type } & \multicolumn{3}{|c|}{ K-feldspar } & \multicolumn{3}{|c|}{ Plagioclase } & \multicolumn{2}{|c|}{ White mica } \\
\hline & $\begin{array}{c}\text { Porphyrocl } \\
\text { ast }\end{array}$ & $\begin{array}{c}\text { New } \\
\text { grai } \\
n\end{array}$ & $\begin{array}{c}\text { Grai } \\
n \text { in } \\
\text { mixe } \\
d \\
\text { zone } \\
s\end{array}$ & $\begin{array}{c}\text { Clas } \\
t \\
\text { core }\end{array}$ & $\begin{array}{l}\text { Clast } \\
\text { rim }\end{array}$ & $\begin{array}{c}\text { Grai } \\
n \text { in } \\
\text { mixe } \\
d \\
\text { zone } \\
s\end{array}$ & $\begin{array}{l}\text { Porphyrocl } \\
\text { ast }\end{array}$ & $\begin{array}{c}\text { Grai } \\
\text { nin } \\
\text { mixe } \\
d \\
\text { zone } \\
s\end{array}$ \\
\hline \multicolumn{9}{|l|}{$\begin{array}{l}\mathrm{Wt} \% \\
\text { oxide }\end{array}$} \\
\hline $\mathrm{SiO}_{2}$ & 66.24 & $\begin{array}{c}64.8 \\
6\end{array}$ & $\begin{array}{c}64.6 \\
6\end{array}$ & $\begin{array}{c}67.6 \\
2\end{array}$ & 68.76 & 7 & 45.72 & $\begin{array}{c}46.6 \\
3\end{array}$ \\
\hline $\mathrm{TiO}_{2}$ & 0.06 & 0.00 & 0.03 & 0.00 & 0.00 & 0.00 & 0.52 & 0.35 \\
\hline $\mathrm{Al}_{2} \mathrm{O}_{3}$ & 18.12 & $\begin{array}{c}18.1 \\
3\end{array}$ & $\begin{array}{c}17.7 \\
9\end{array}$ & $\begin{array}{c}19.7 \\
4\end{array}$ & 19.87 & $\begin{array}{c}19.7 \\
7\end{array}$ & 33.42 & $\begin{array}{c}30.2 \\
7\end{array}$ \\
\hline $\mathrm{FeO}$ & 0.00 & 0.00 & 0.12 & 0.08 & 0.00 & 0.00 & 31.37 & 3.17 \\
\hline $\mathrm{MnO}$ & 0.00 & 0.01 & 0.00 & 0.03 & 0.03 & 0.00 & 0.00 & 0.08 \\
\hline $\mathrm{MgO}$ & 0.02 & 0.00 & 0.00 & 0.00 & 0.03 & 0.00 & 0.81 & 1.55 \\
\hline $\mathrm{CaO}$ & 0.00 & 0.00 & 0.00 & 0.96 & 0.69 & 1.49 & 0.00 & 0.00 \\
\hline $\mathrm{Na}_{2} \mathrm{O}$ & 0.55 & 0.54 & 0.43 & $\begin{array}{c}10.9 \\
7\end{array}$ & 11.30 & $\begin{array}{c}10.6 \\
6\end{array}$ & 0.75 & 0.16 \\
\hline $\mathrm{K}_{2} \mathrm{O}$ & 15.91 & $\begin{array}{c}16.1 \\
6\end{array}$ & $\begin{array}{c}16.2 \\
2\end{array}$ & 0.16 & 0.08 & 0.18 & 10.44 & $\begin{array}{c}11.0 \\
5\end{array}$ \\
\hline Total & 100.90 & $\begin{array}{c}99.7 \\
0 \\
\end{array}$ & $\begin{array}{c}99.2 \\
5\end{array}$ & $\begin{array}{c}99.5 \\
6 \\
\end{array}$ & $\begin{array}{c}100.7 \\
5 \\
\end{array}$ & $\begin{array}{c}98.3 \\
7 \\
\end{array}$ & 93.03 & $\begin{array}{c}93.2 \\
6 \\
\end{array}$ \\
\hline \multicolumn{9}{|l|}{$\begin{array}{l}\text { Formu } \\
\text { la }\end{array}$} \\
\hline $\mathrm{Si}$ & 3.04 & 3.01 & 3.01 & 2.98 & 2.99 & 2.96 & 3.12 & 3.21 \\
\hline $\mathrm{Ti}$ & 0.00 & 0.00 & 0.00 & 0.00 & 0.00 & 0.00 & 0.03 & 0.02 \\
\hline $\mathrm{Cr}$ & 0.00 & 0.00 & 0.00 & 0.00 & 0.00 & 0.00 & 0.00 & 0.00 \\
\hline $\mathrm{Al}$ & 0.98 & 0.99 & 0.98 & 1.03 & 1.08 & 1.04 & 2.69 & 2.46 \\
\hline $\mathrm{Fe}$ & 0.00 & 0.00 & 0.01 & 0.00 & 0.00 & 0.00 & 0.08 & 0.25 \\
\hline Mn & 0.00 & 0.00 & 0.00 & 0.00 & 0.00 & 0.00 & 0.00 & 0.00 \\
\hline $\mathrm{Mg}$ & 0.00 & 0.00 & 0.00 & 0.00 & 0.00 & 0.00 & 0.08 & 0.16 \\
\hline $\mathrm{Ca}$ & 0.00 & 0.00 & 0.00 & 0.05 & 0.03 & 0.07 & 0.00 & 0.00 \\
\hline $\mathrm{Na}$ & 0.05 & 0.05 & 0.04 & 0.94 & 0.95 & 0.92 & 0.10 & 0.02 \\
\hline $\mathrm{K}$ & 0.93 & 0.96 & 0.96 & 0.01 & 0.00 & 0.01 & 0.91 & 0.97 \\
\hline Total & 5.00 & 5.00 & 5.00 & 5.00 & 5.00 & 5.00 & 7.00 & 7.00 \\
\hline $\begin{array}{l}\text { XMg } \\
\text { molar }\end{array}$ & & & & & & & 0.51 & 0.39 \\
\hline
\end{tabular}

Note. $\mathrm{XMg}$ molar $=\mathrm{Mg} /(\mathrm{Mg}+\mathrm{Fe})$ 


\section{Highlights}

- Grain size reduction and phase mixing increases with increasing strain.

- Phase nucleation is the major process behind phase mixing.

- Phase nucleation is driven by chemical reactions and grain-boundary sliding.

- Succession in weakening processes related to the accumulation of strain itself. 


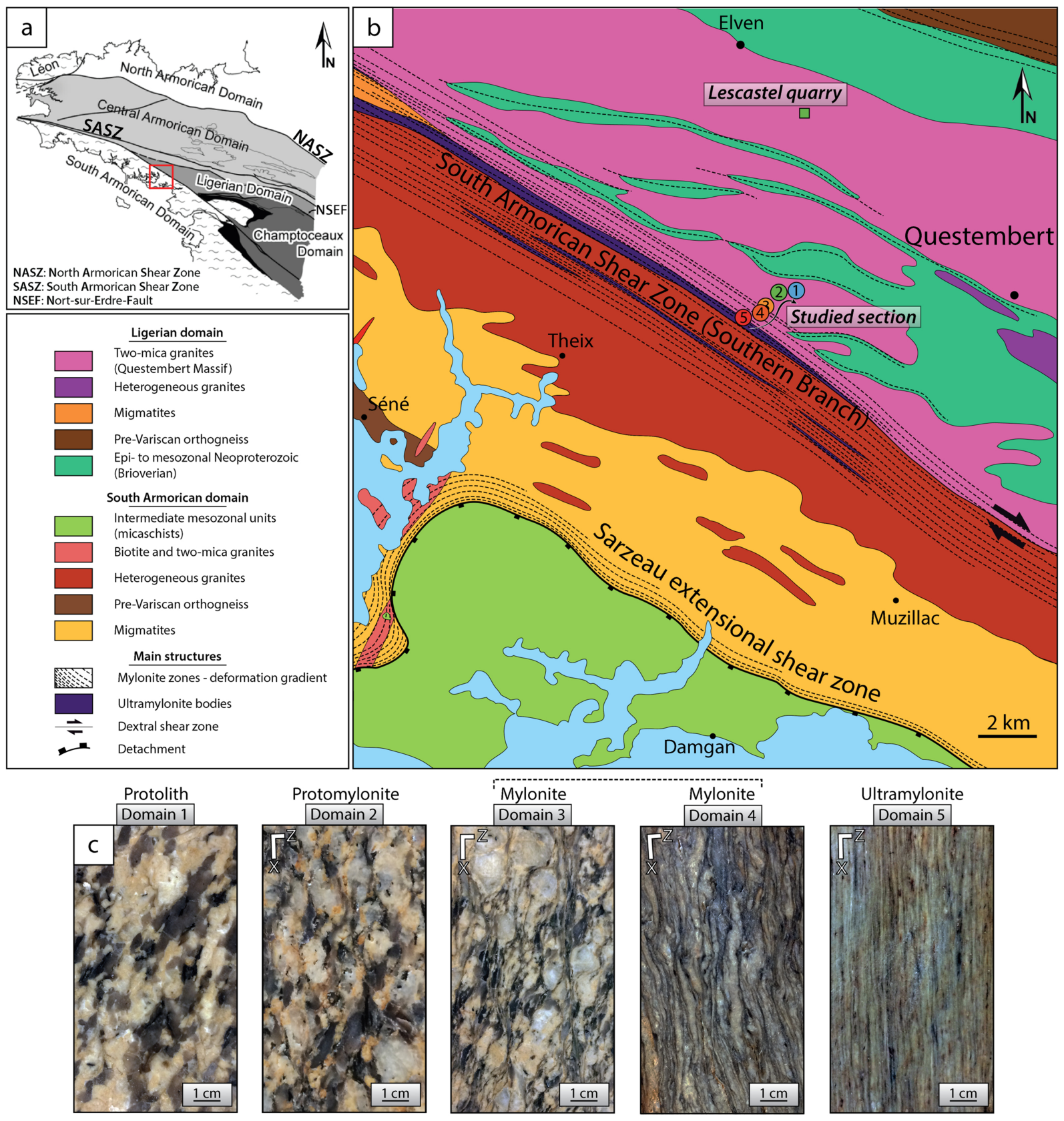

Figure 1 

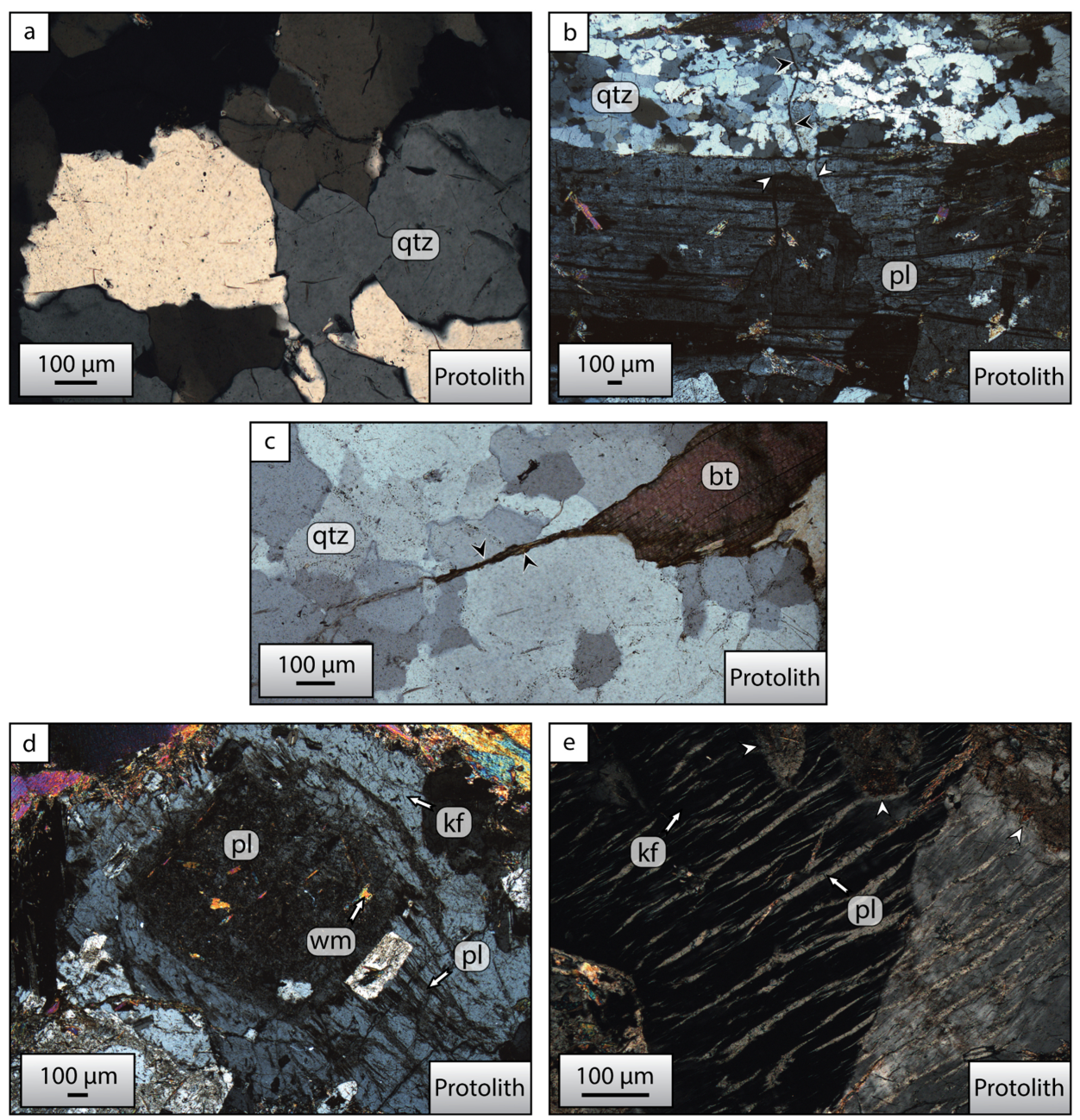

Figure 2 

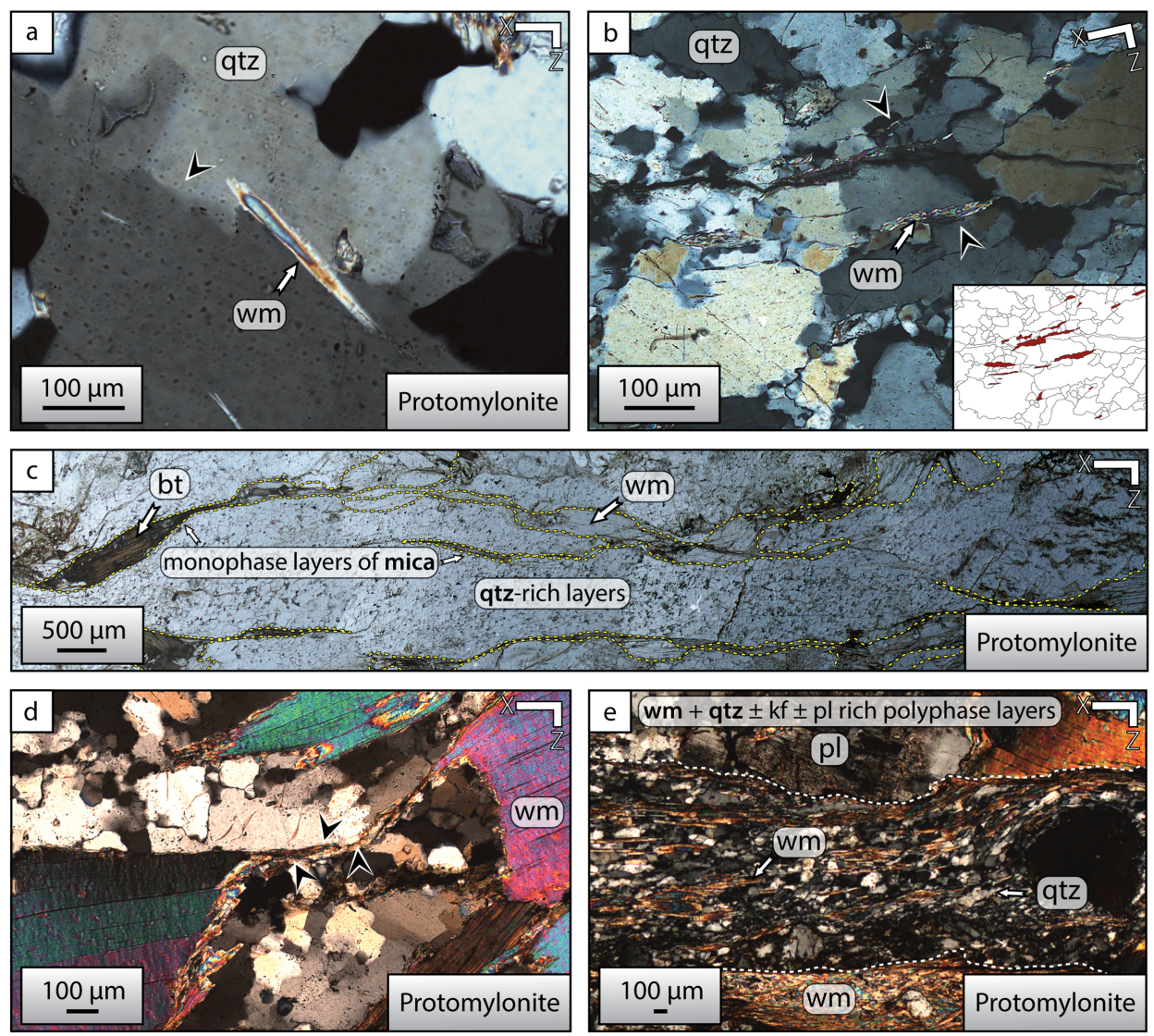

Figure 3 

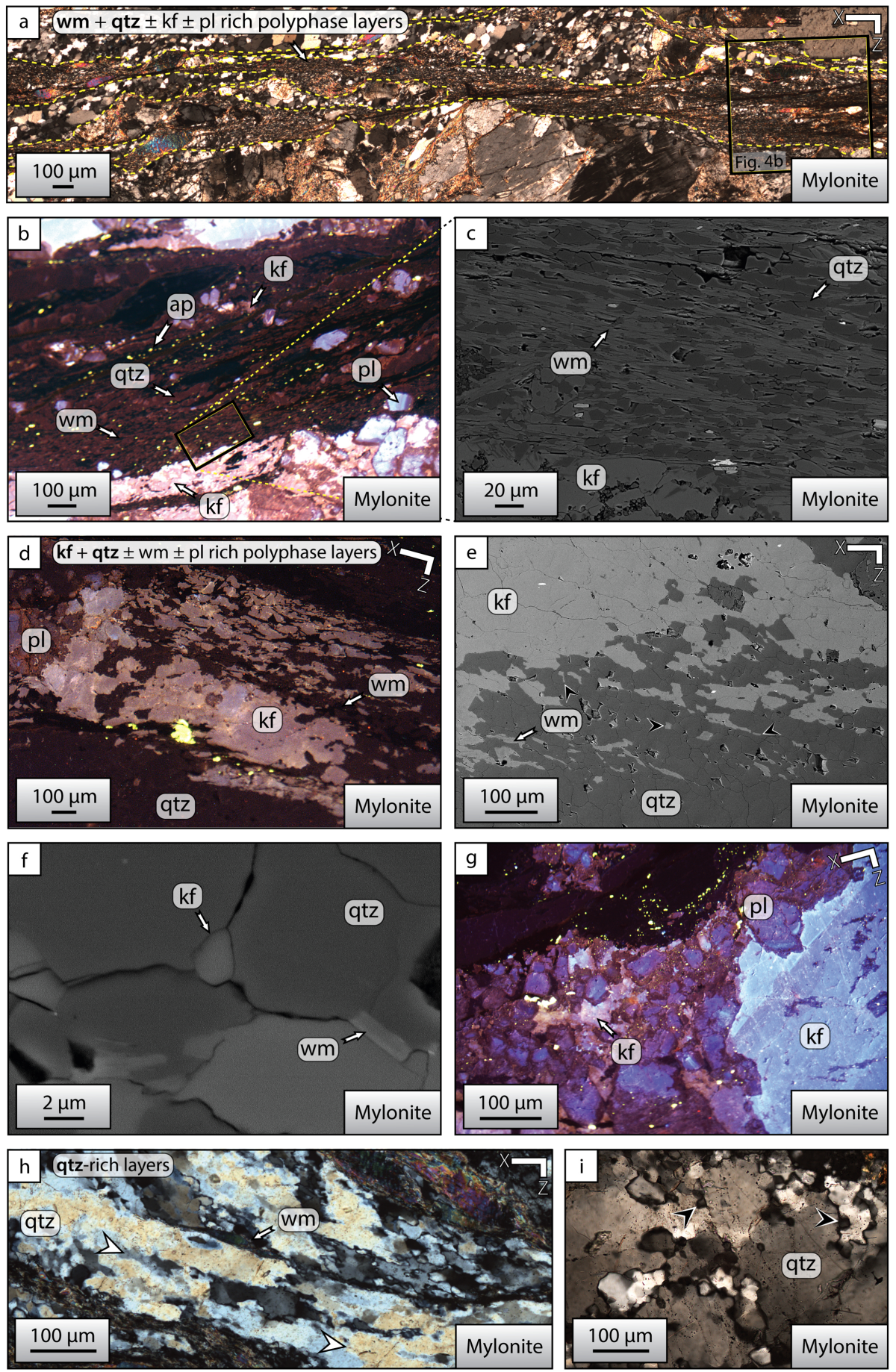


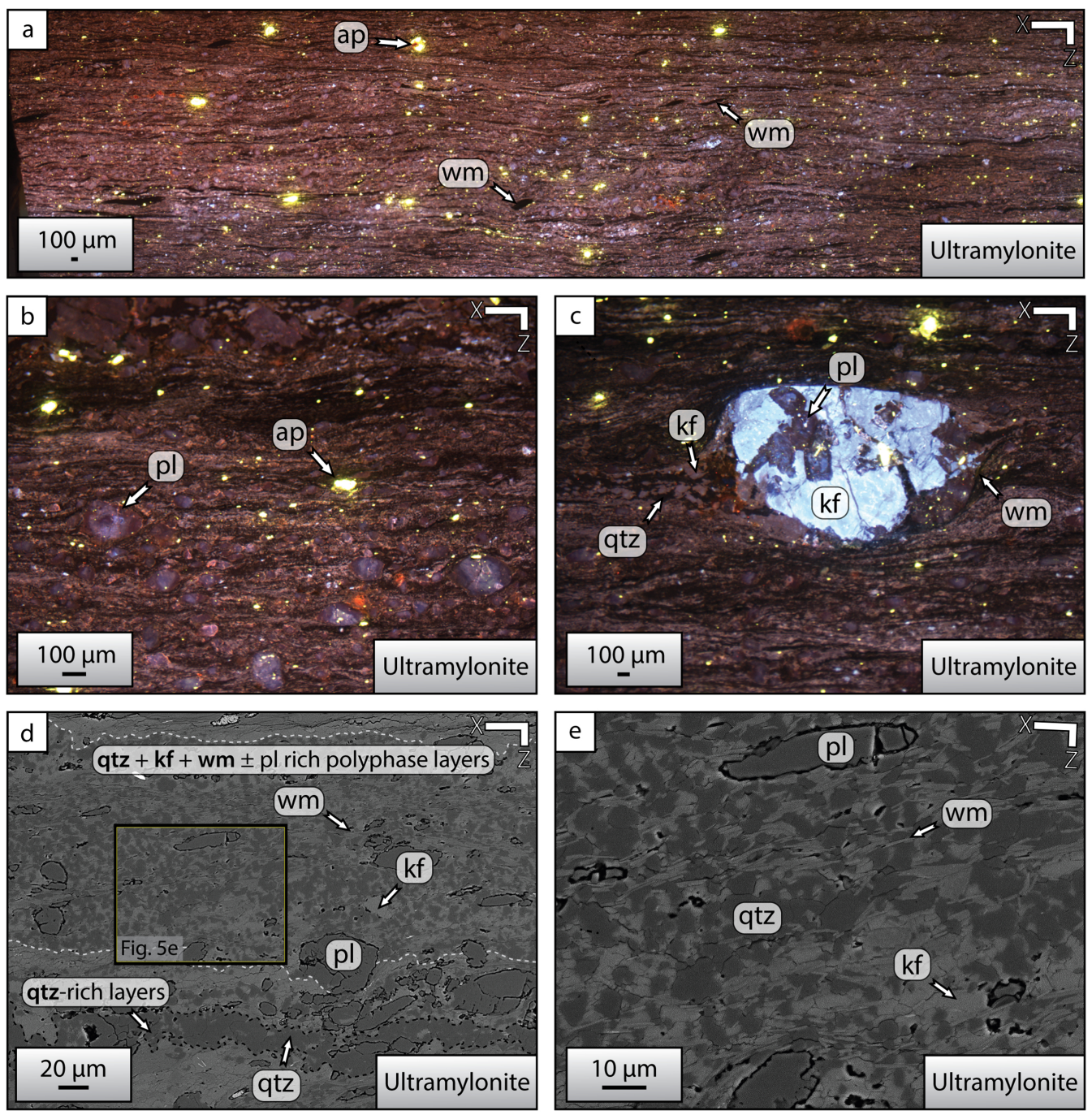

Figure 5 


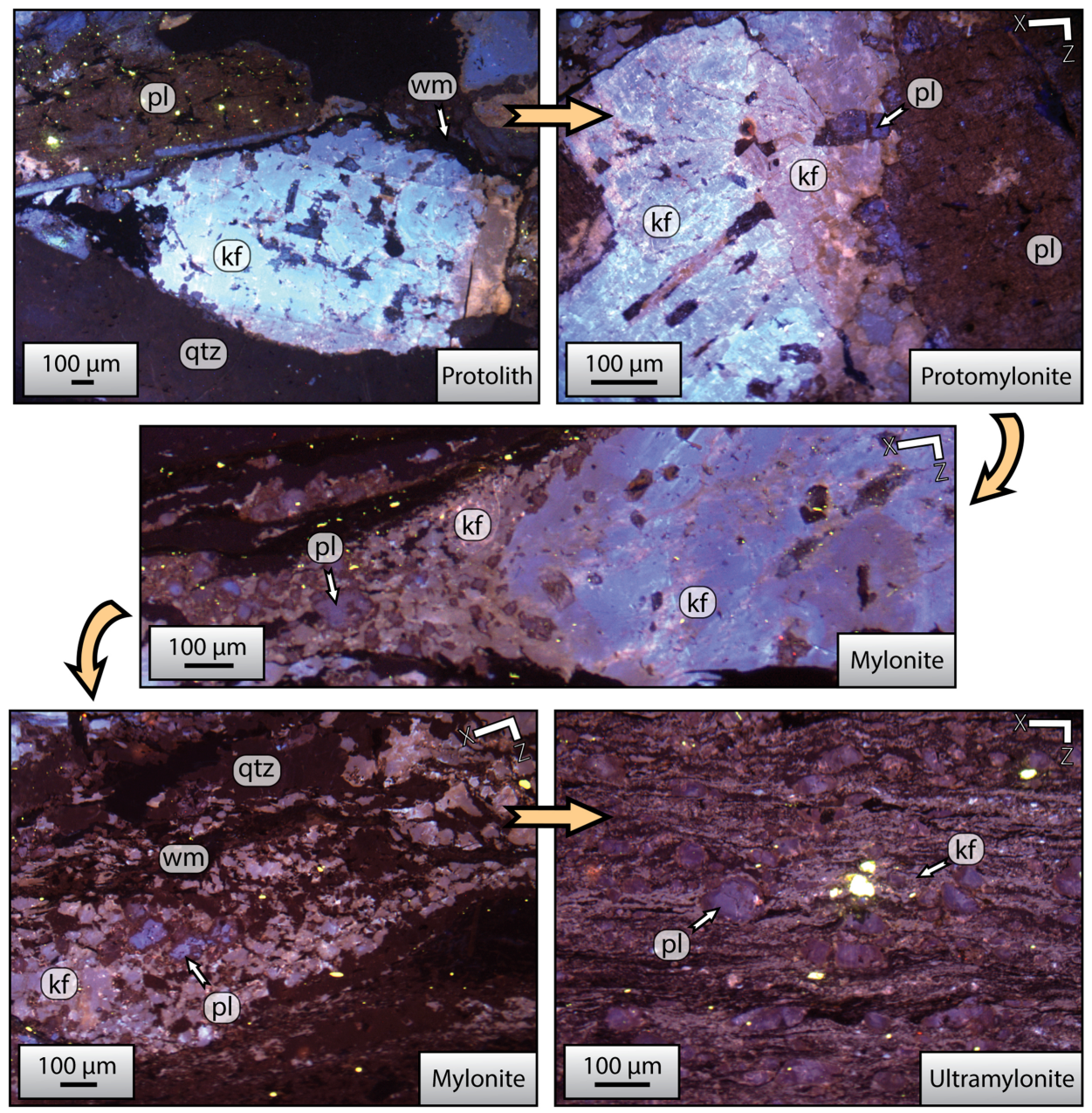

Figure 6 

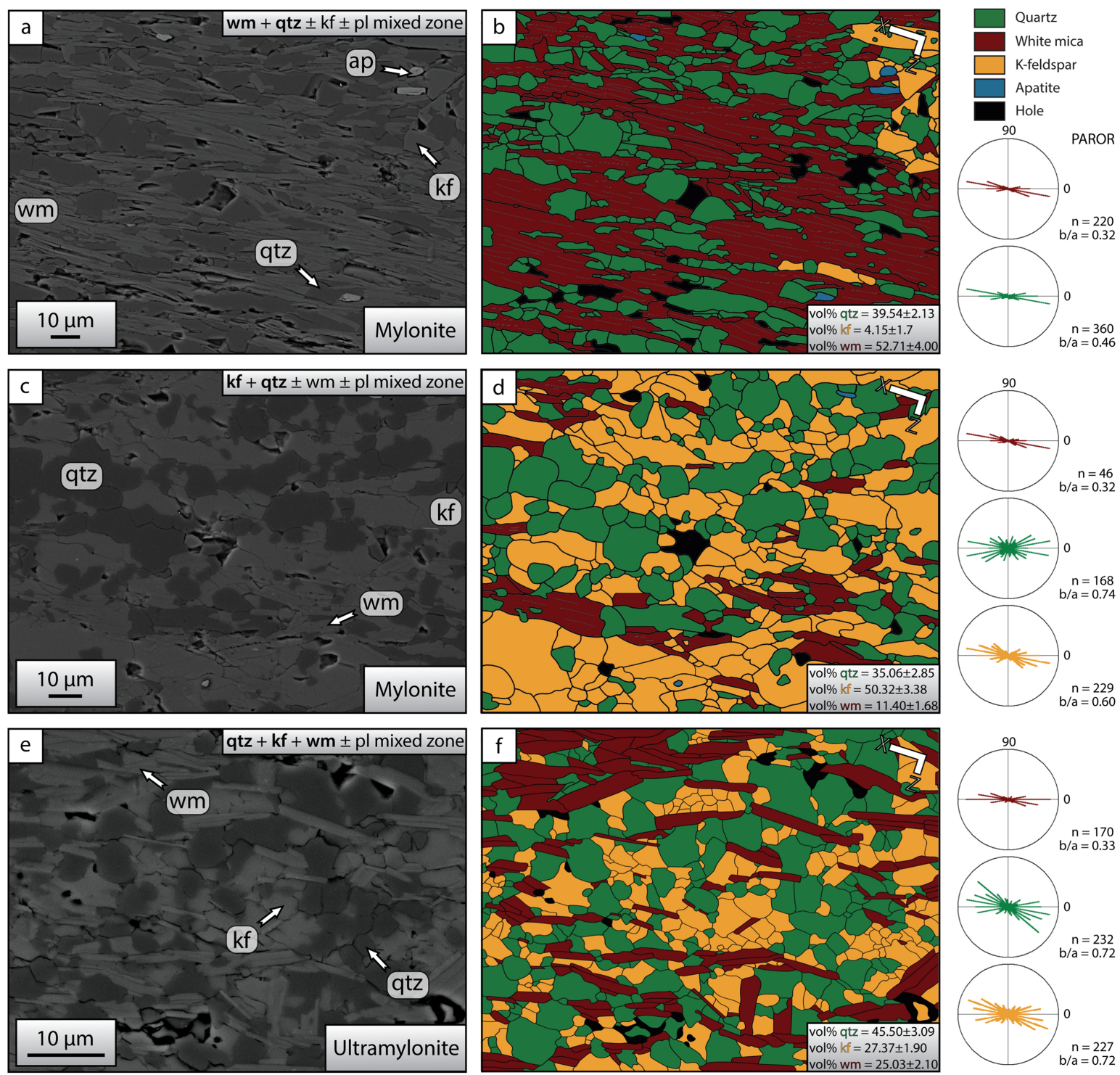

Figure 7 


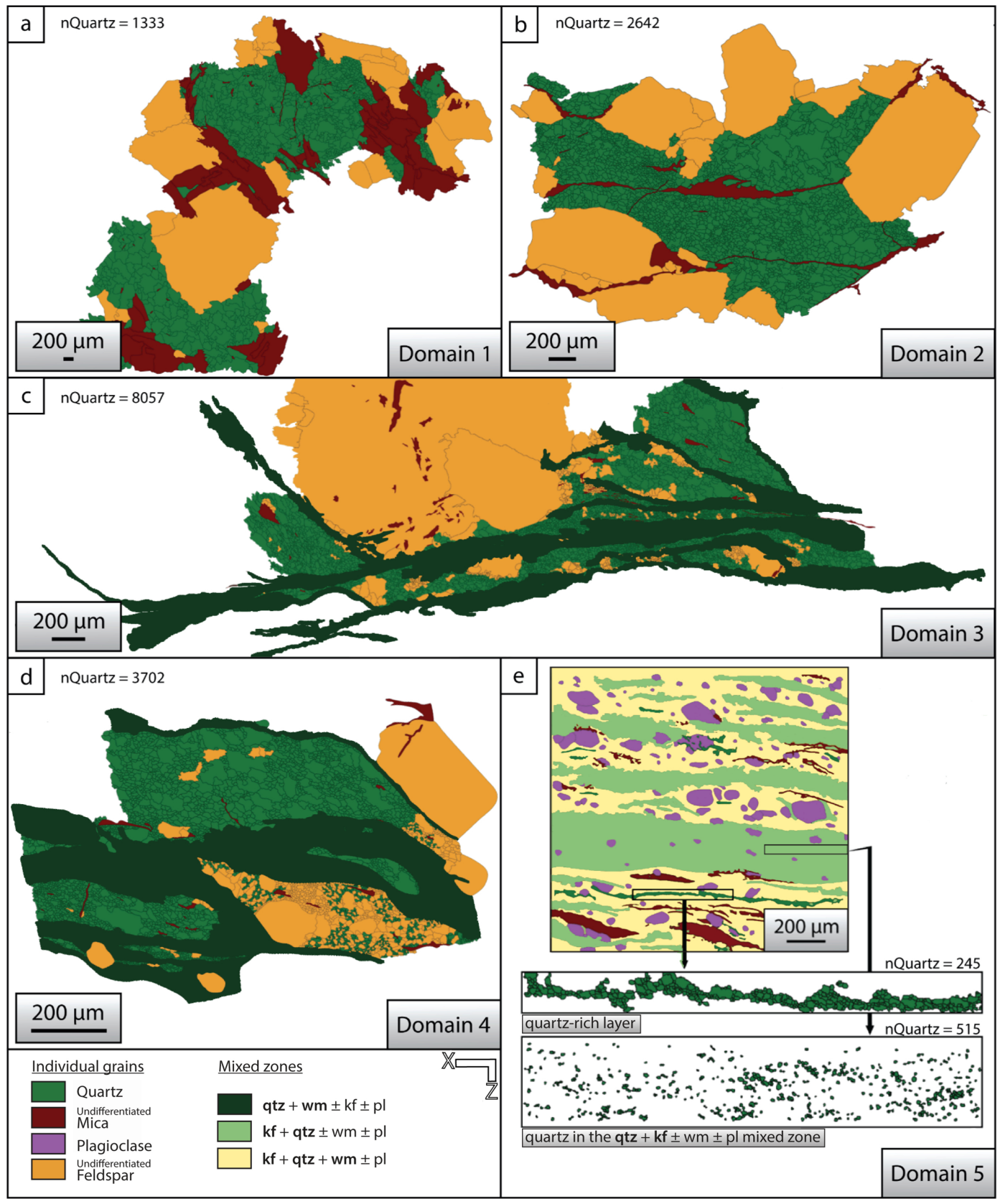

Figure 8 


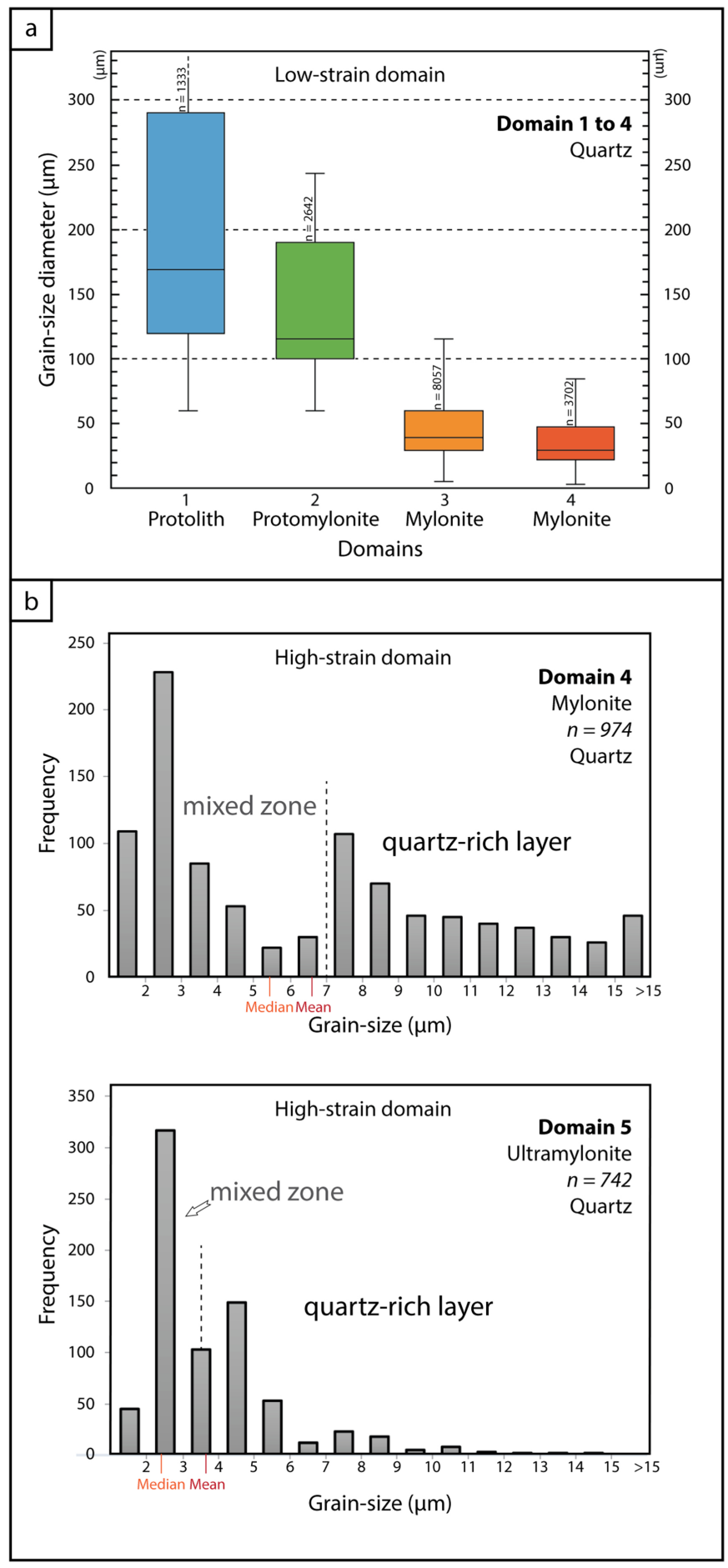

Figure 9 

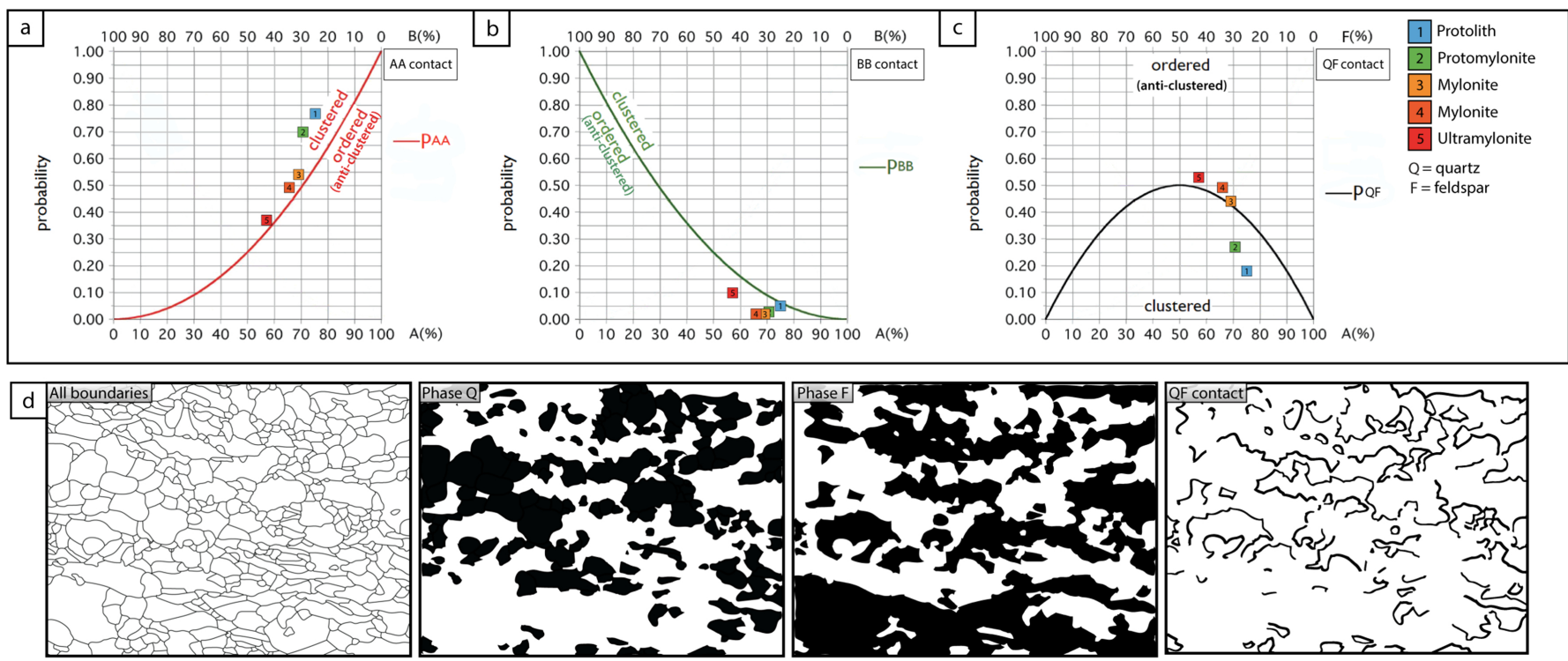

Figure 10 

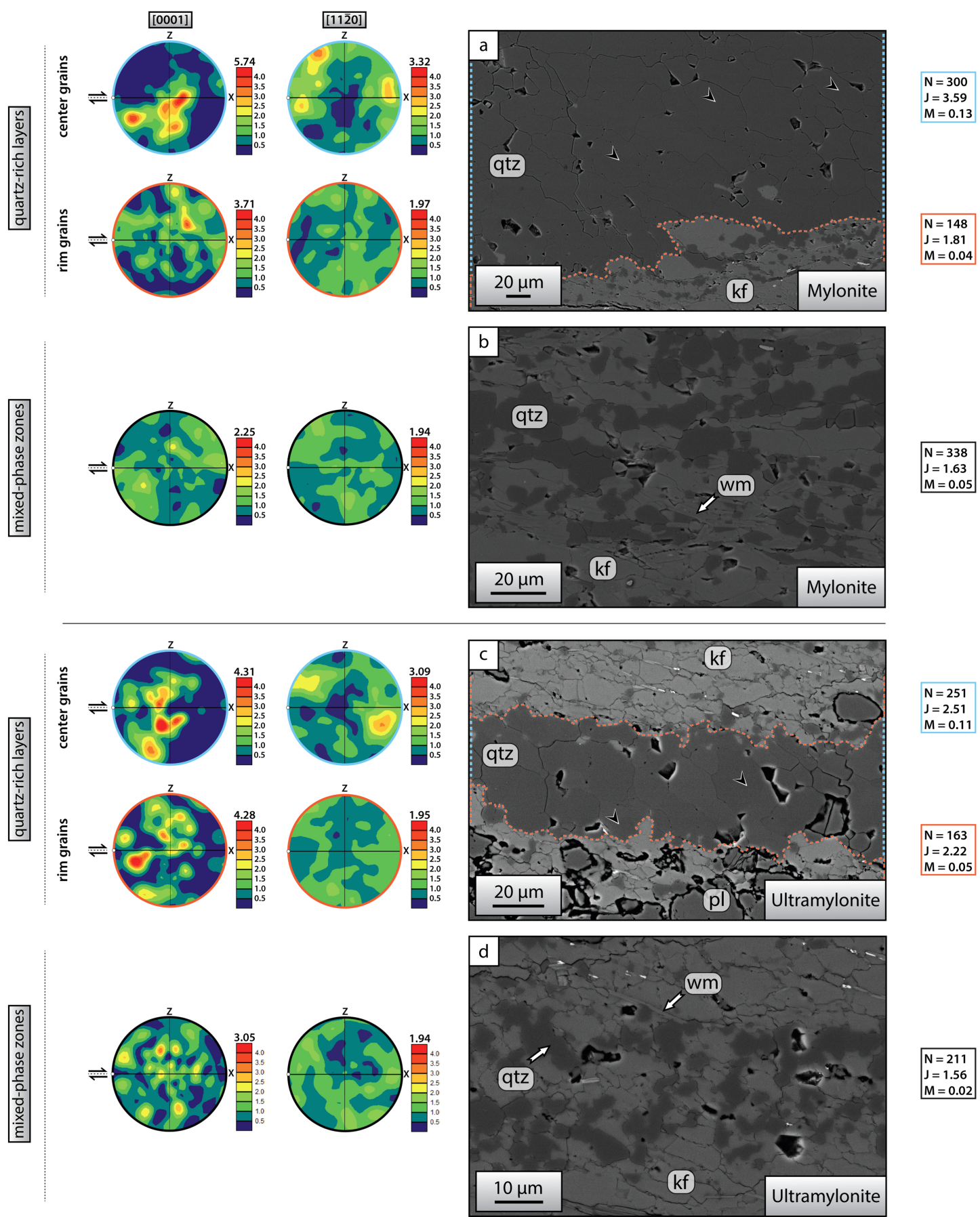

$J=1.56$
$M=0.02$ 


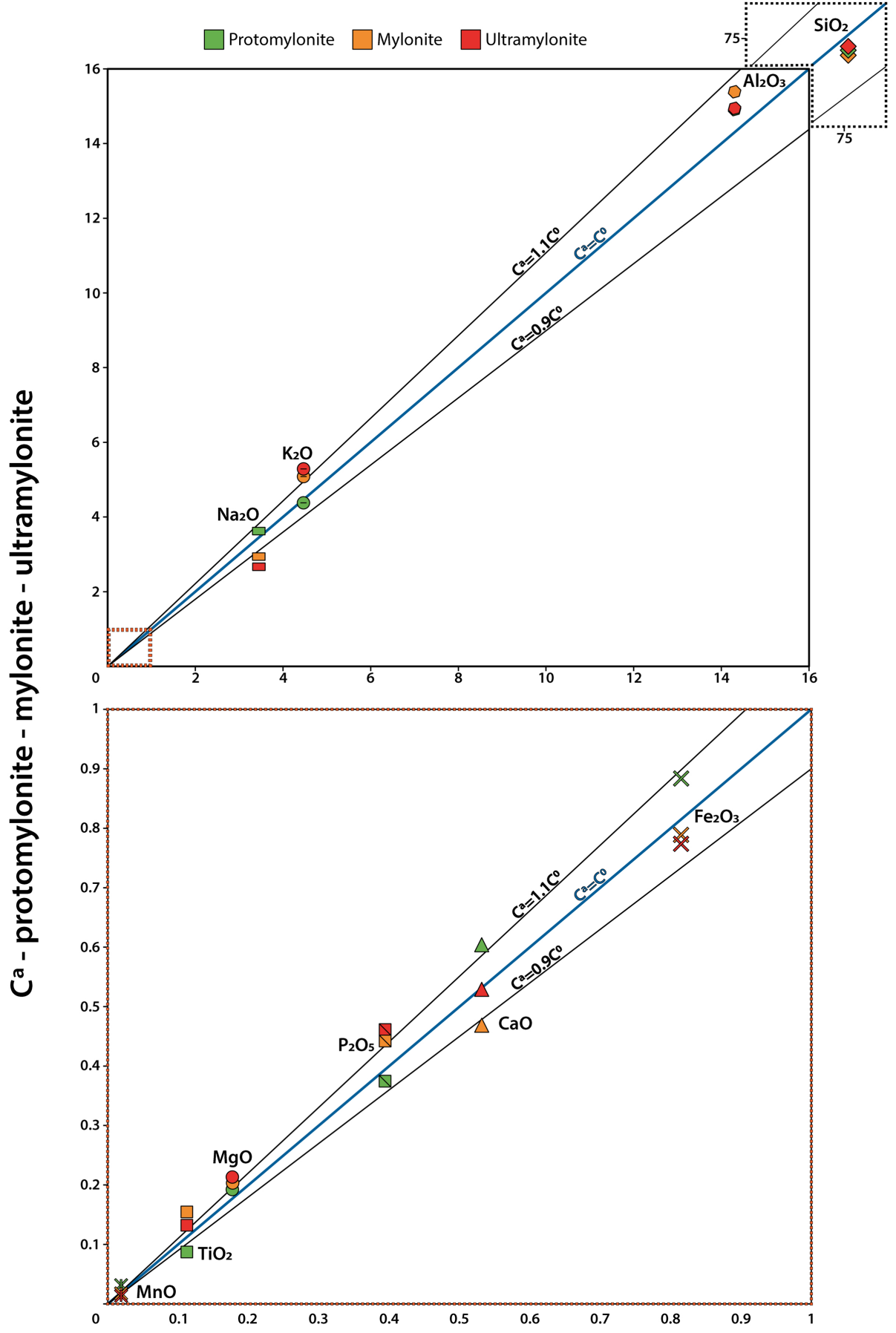

Figure 12 


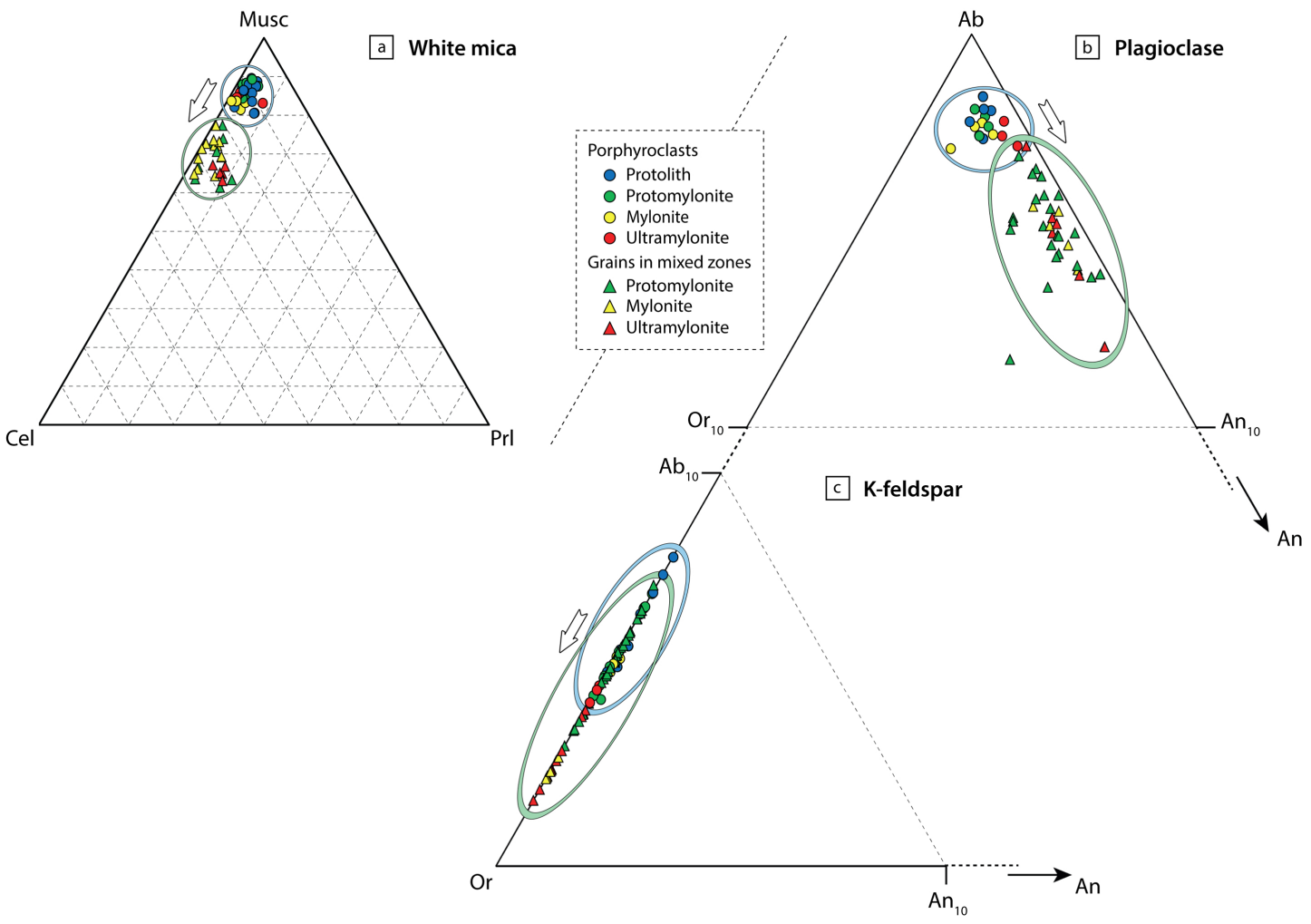

Figure 13 

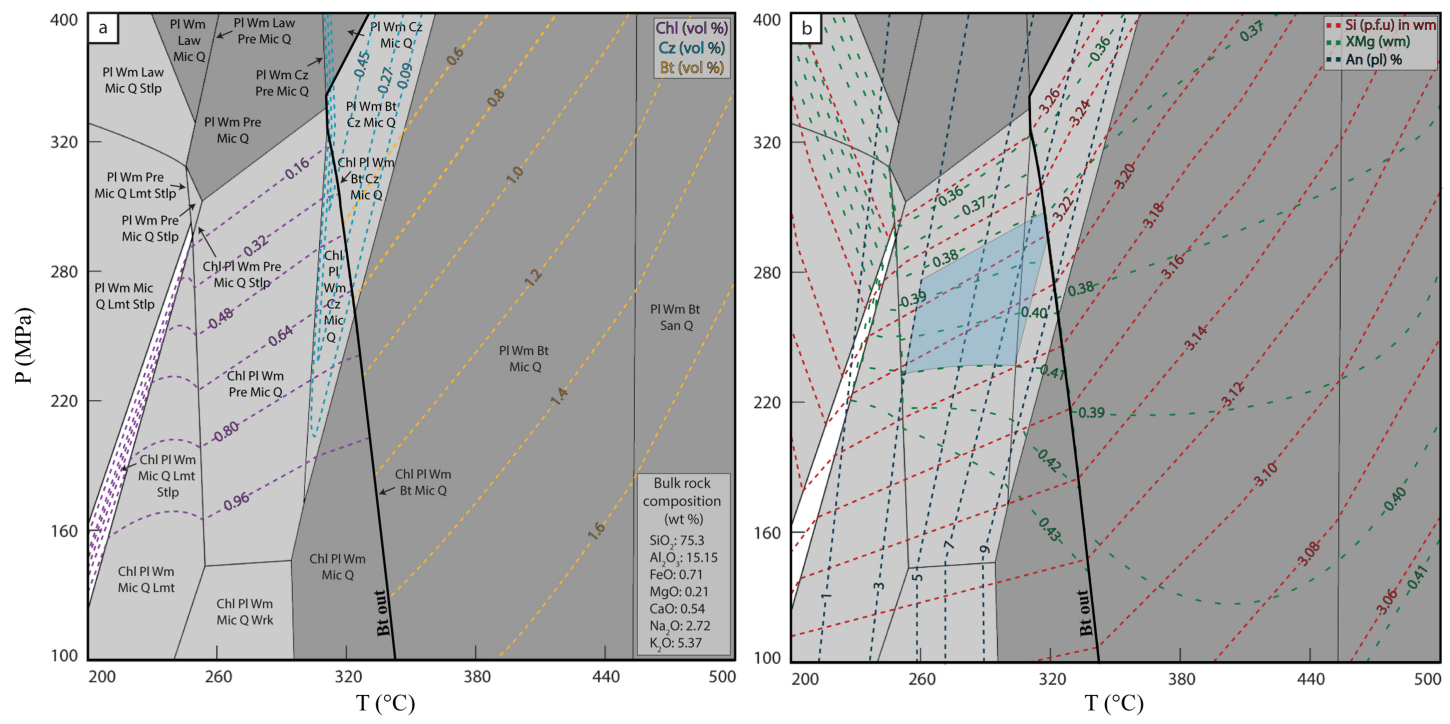

Figure 14 